\title{
La escenificación del poder: el marqués de Castelldosrius, primer virrey Borbón del Perú (1707-1710)
}

Núria Sala i Vila

Universitat de Girona

El cambio dinástico comportó una serie de cambios en la cultura política virreinal peruana. Se analiza el gobierno del marqués de Castelldosrius (1707-1710), quien atenuaría sus conflictos con sectores criollos y del Consulado por su afán de acrecentar su magro patrimonio, con un estilo de ejercer la política, caracterizado por usos cortesanos y culturales que incorporaban tradiciones en boga en la corte de Luis XIV y en su Cataluña natal.

Palabras clave: Cultura política, virrey, Castelldosrius, Perú, Borbones.

The change in dynasty brought with it a series of transformations to Peruvian viceroyalty political culture. Analysis is made of the government of the Marquis of Castelldosrius (1707-1710) who, in his eagerness to increase a meagre patrimony, was to attenuate his conflicts with the Creole sectors and the Consulate, with a style of politics that was characterised by courtly and cultural uses that included traditions that were in vogue in the courts of Louis XIV and in his native Catalonia.

Keywords: Political culture, Viceroy, Castelldosrius, Peru, Bourbons.

Pensar históricamente no puede disociarse de la experiencia personal de quien escribe en clave del pasado para comprender el presente. Durante años he ido anotando, por curiosidad o simpatía, cuanto apellido catalán encontraba en los documentos coloniales que he consultado, en mi empeño, a veces vano, siempre sugerente y apasionante, de comprender el Perú. Era como una suerte de mirada de reojo y de sorpresa ante la huella de catalanes, quienes a priori y de seguir las tesis defendidas por las tendencias historiográficas dominantes, éramos ajenos, en gran medida, al devenir histórico del mundo colonial hispano, hasta avanzado el siglo XVIII. Las preguntas a los silencios historiográficos y la evidencia de los datos recopilados a lo largo de más de dos décadas se entrecruzaron, al punto que empecé a preguntarme porque no existe una tradición historiográfica que incluya o compare el devenir de gentes y territorios que compartieron una misma corona e idéntico proyecto estatal. Las páginas que vienen a continuación intentan ser un esbozo en ese sentido, se trata de comprender los bagajes políticos y culturales que trajeron consigo actores catalanes en el virreina- 
to del Perú, en un tiempo, el temprano siglo XVIII, marcado por el cambio dinástico y la reorientación de la administración colonial. Se trata de comprender que similitudes, divergencias y circuitos de comunicación existieron entre territorios como Cataluña y Perú, ${ }^{1}$ que formaron parte de la Monarquía Hispánica y a qué políticas se vieron sometidas, más allá de aquellas más conocidas entre los Reinos de Indias y la Corona de Castilla. ${ }^{2}$

La historiografía reciente sobre el reformismo borbónico ha puesto énfasis en la política de Carlos III y Carlos IV, sin embargo, como ha señalado recientemente A. Moreno Cebrián, ${ }^{3}$ queda pendiente comprender los cambios y continuidades en la administración colonial de los primeros borbones, para visualizar el alcance y profundidad de la nueva orientación política en la segunda mitad del siglo XVIII.

La nueva dinastía marcaría una serie de cambios en el sentido estricto del ejercicio del poder y la concepción del estado, en pos de lograr la centralización y homogeneización política y cultural. Los decretos de Nueva Planta anularon los fueros privativos de los territorios de la Corona de Aragón - Aragón, Cataluña y Valencia - y vetaron el uso oficial de la lengua catalana. En el aspecto cultural, como ha propuesto Jaume Tortella, en lo que ha denominado "la nueva planta cultural", se impuso un viraje hacia presupuestos absolutistas y centralizadores, que se plasmaría en la creación, bajo tutela estatal de Academias, la Biblioteca Real, gabinetes de Historia Natural, el Jardín Botánico, la reforma universitaria, junto con una mayor injerencia en la edición de libros y la instrumentalización del teatro y la música. ${ }^{4}$

Los funcionarios fueron reclutados inicialmente en sectores sociales de probada lealtad. Mientras Cataluña se levantaba en armas en defensa del partido austriacista, nobles connotados felipistas, botiflers en la memoria

1 Trabajo preliminar dentro del proyecto "Els virreis catalans del Borbó: reforma política, renovació cultural i rearmament cultual (Perú, s.XVIII)" subvencionado por el programa de Beques per a la recerca a fora de Catalunya, concedida por la Agència de Gestió d'Ajuts Universitaris i de Recerca, data de resolució de convocatòria 15 de gener de 2003, núm. DOGC 3812 i data de 31 de gener de 2002, núm. d'expedient 2003BEA1400323.

2 Debo agradecer la ayuda a lo largo de la investigación de Francesc Miralpeix, Xavier Torres, J.M. Puigvert, Albert Rossic, J.A. Rodríguez, Alfredo Moreno Cebrián y la lectura atenta de Clara López Beltrán y Roser Vila. Sin la paciencia y las sugerencias de Charles F. Walker no habría llegado a redactarse. Un avance fue presentado en el $X$ Encuentro de Latinoamericanistas, celebrado en Salamanca el 13 y 14 de mayo de 2004. Cualquier error es de mi propia responsabilidad.

3 Moreno Cebrián, Alfredo: El virreynato del marqués de Castelfuerte, 1724-1736. El primer intento borbónico por reformar el Perú. Madrid, Catriel, 2000.

4 Tortella, Jaume: "Legislación en el cambio dinástico: "La nueva planta cultural". Manuscrits, 18, 2000, págs. 141-160. 
catalana, fueron incorporados en cargos relevantes en la administración central y por primera vez en la indiana. A modo de ejemplo destacaría los virreyes de Nueva España, Joaquim de Montserrat i de Cruïlles, marqués de Cruïlles (1760-1766), y Fèlix Berenguer i de Marquina (1799-1804); de Nueva Granada, Joseph Solís Folch de Cardona (1753-1761); y del Perú, marqués de Castelldosrius (1707-10) y Manuel Amat i Junyent (1761-1776), hermano del marqués de Castellbell. Fue el punto de quiebre en una larga tendencia durante la cual se confirieron tales cargos a miembros de la nobleza castellana, lo que llamó ya la atención de G.Lohmann Villena y de A. Saénz-Rico. ${ }^{6}$ Supondría una de las complejas consecuencias del reformismo borbónico, ya que abolía los fueros privativos de la Corona de Aragón, al mismo tiempo que incorporaba a la estructura administrativa colonial a sectores de la nobleza catalana, en la medida que los Reinos de Indias se habían mantenido vinculados a la Corona de Castilla y, en general, a sus súbditos.

Los pocos estudios existentes sobre el papel relevante de la nobleza catalana en la administración borbónica pueden ser un indicador del número limitado de investigaciones sobre la nobleza de la Corona de Aragón en la Edad Moderna, sobre todo si los comparamos con los que existen sobre la nobleza castellana y su proyecto cortesano, en palabras de Domínguez Ortíz, ${ }^{7}$ en pos de ricas prebendas, o de unos años en los virreinatos de Nápoles o Perú, con que restaurar sus magras haciendas. Para el caso catalán, destacan los trabajos de P. Molas y Ribalta, quien ha estudiado la vinculación de la nobleza a la administración del estado bajo los Austrias y sus actitudes durante los Borbones. ${ }^{8}$ Eva Serra se centró en la relaciones socioeconómicas entre campesinos y nobleza tomando como base el análisis de las rentas señoriales disponibles en el fondo patrimonial de los marqueses de Castelldosrius, ${ }^{9}$ mientras que J. Amelang ${ }^{10}$ ha destacado la imporpágs. 101-128

6 Saénz-Rico, Alfredo: El Virrey Amat: precisiones sobre la vida y la obra de Don Manuel de Amat y de Junyent. Barcelona, Museo de Historia de la Ciudad, 1967, 2v.

7 Domínguez Ortíz, Antonio: "La nobleza como estamento y grupo social en el siglo XVIII". En: Nobleza y sociedad en la España Moderna. Madrid, Fundación Central Hispano, 1996, págs. 113-133.

8 Molas, Pere: "Catalans a l'administració central al segle XVIII". Pedralbes, 8-II, 1988, págs. 181-195; "Catalans als Consells de la Monarquia (segles XVII-XVIII). Documentació notarial". Estudis històrics $i$ documents dels Arxius de Protocols, XIII, 1995, pág. 229-230; "Els cavallers catalans de l'Orde de Carles III". Pedralbes, 16, 1996, págs. 61-95.

9 Serra, Eva: Pagesos i senyors a la Catalunya del segle XVII. Baronia de Sentmenat, 15101729. Barcelona, Crítica, 1988.

10 Amelang, James: La formación de una clase dirigente: 1490-1714. Barcelona, Ariel, 1986. 
tancia de la cultura en la formación de una élite urbana, imbricada de burgueses y nobles, en la Barcelona del XVII y temprano XVIII. Otro de los factores que debemos considerar es que la reciente historiografía catalana se ha dirigido a entender los proyectos que fueron derrotados en la Guerra de Sucesión, ${ }^{11}$ cuando Cataluña abrazó mayoritariamente el partido austriacista, lo que para ciertos autores supuso el inicio del proyecto centralista y unificador borbónico o la formación del estado-nación en España. ${ }^{12}$

Trataré de abordar con un estudio de caso, la escenificación del poder y la cultura política del primer virrey borbónico en el Perú, el I marqués de Castelldosrius (1707-1710), quién llegó al cargo tras culminar una larga carrera en la administración del estado. Se trata de indagar en que medida coadyuvó a la circulación de ideas, convertido en actor consciente o inconsciente del contacto entre el pensamiento y las mentalidades predominantes entre Cataluña y Perú, en aquellos espacios en donde hubo de ejercer sucesivos cargos políticos.

La documentación que sustenta este estudio proviene tanto de la generada en distintas instancias de la administración del estado, como de carácter privado - patrimonial, correspondencia,...- depositada en el fondo Castelldosrius, en el Archivo Nacional de Cataluña, ${ }^{13} \mathrm{o}$ de manuscritos y ediciones que recopilan su actividad intelectual.

Manuel de Oms de Santapau olim Sentmenat i de Lanuza (Barcelona1651-Lima 1710) ${ }^{14}$ era miembro de una antigua familia nobiliaria catalana. Marqués de Castelldosrius (Carlos II, Real Decreto, Buen Retiro, 25.4.1690 y Real Despacho, Madrid, 6.4.1696), 11. Barón de Dosrius y Señor de Cayamars, 17. ${ }^{\circ}$ Barón de Santa Pau, Vasvesor de Montescot, Señor de Oms (con imposición del apellido Oms de Santa Pau) desde 1694. Cursó estudios y se doctoró en filosofía por la Universidad de Barcelona en 1665. Siguió la carrera militar, siendo sucesivamente Capitán de Caballos (16671669) del lugarteniente de Cataluña, duque de Osuna; participó en las campañas del Rosellón (1674-75); fue sucesivamente gobernador de Castell-lleó

11 Albareda, Joaquim: Els catalans i Felip V, de la conspiració a la revolta (1700-1705). Barcelona, Vicens Vives, 1993; Felipe Vy el triunfo del absolutismo: Cataluña en un conflicto europeo (1700-1714). Barcelona, Generalitat de Catalunya, 2002. Lluch, Ernest: Las Españas vencidas del siglo XVIII. Claroscuros de la Ilustración. Barcelona, Crítica, 1999.

12 García Cárcel, Ricardo: Felipe V y los españoles: una visión periférica del problema de España. Barcelona, Plaza y Janes, 2002.

13 Fernández, J., Badala, F., Martí, C.: El fons dels marquesos de Castelldosrius. Barcelona, Generalitat de Catalunya, Departament de Cultura, 1990.

14 Antepuso los apellidos a los suyos a raíz del testamento de su cuñado, Antonio, junto a los bienes de la casa de Oms y la baronía de Santa Pau. 
(1676), de Tarragona (1677-1680), virrey del Reino de Mallorca (16811688), Protector Presidente del Brazo Militar de Cataluña (1688-1691), miembro del Consejo de Guerra en 1689 "en atención a los muchos méritos y servicios", ${ }^{15}$ habilitado como Noble en las Cortes de Cataluña en 1701 y 1702; embajador en Portugal (1691-1698) y Francia (1698-1701). ${ }^{16}$

El linaje Castelldosrius mantuvo posiciones enfrentadas a los franceses durante la Guerra dels Segadors (1640-1652). Ramon de Sentmenat i Lanuza, obispo de Vic y Barcelona, sería expulsado de su mitra en Vic en 1646, al mismo tiempo que Enric Sentmenat i Lanuza, barón de Dosrius, padre de nuestro personaje, perdía parte de su patrimonio en la Cataluña Norte, luego del tratado de los Pirineos. Según J. Alvareda, habría que situar la concesión del marquesado de Castelldosrius dentro de la política de Carlos II por atraerse a una nobleza dominada por la francofobia, resultado de la larga actividad bélica en Cataluña -1640-1651, 1653-1659, 1667-1668, 1689-1697_, como consecuencia del enfrentamiento entre la Monarquía Hispánica y Francia, en lo que denomina el marco expansivo del absolutismo, con sus altos costos para Cataluña por el mantenimiento de las fuerzas militares y las pérdidas territoriales al norte de los Pirineos. ${ }^{17}$ En ese período sus peticiones a la Corona reflejan un sentimiento anti-francés y la necesidad de obtener cargos como funcionario, para recuperarse de las adversidades en su patrimonio.

Su sentir y destino cambiaría cuando, ya destacado como embajador en París, sería el encargado de transmitir el testamento de Carlos II a Luis $\mathrm{XIV}$, por el que nombraba heredero al trono a su nieto, Felipe V. En esa etapa, un testigo de primera línea, el duque de Saint-Simon, se refiere a él como "gentilhomme catalan fort pauvre", "un très bon, honnête et galant homme, à qui la tête ne tourna ni manqua dans cette conjoncture si extraordinaire et si brillante, poli et considéré, et qui se fit aimer et estimer de tour le monde". De aceptar su testimonio, Luis XIV le premió con 3.000 luises de oro, la Grandeza de España y "la vice-royauté du Pérou por l'enrichir". ${ }^{18}$

15 Arxiu Històric Nacional de Catalunya (en adelante AHNC). Fons dels marquesos de Castelldosrius (en adelante FMC). 1242.19.310. Decreto Marqués de Mont Real, 20 de septiembre de 1689.

16 Castan i Ranch, Amèlia: "Nobleza y poder en la Cataluña de la época moderna: una aproximación biográfica al primer marqués de Castelldosrius (1651-1710)". Pedralbes, 13-I, 1993. Fluviá, Armando de: "La casa de Sentmenat. Línea de los marqueses de Castelldosrius, Grandes de España". Hidalguía, año XV, n. ${ }^{\circ}$ 80, en-feb. 1967, págs. 353-376.

17 Albareda, Joaquim: Felipe V..., págs. 23-38.

18 Rouvroy, Louis de, duc de Saint-Simon: Memoires. París, Gallimard, 1983-1990, t. I, págs. 663 y $796-7$. 
Y ese fue su objetivo, remontar su patrimonio, más aún cuando sus bienes sufrieron los avatares de la Guerra de Sucesión, al ser confiscados por los austriacistas, desde 1705 hasta la toma de Barcelona en 1714 por las tropas de Felipe V. ${ }^{19}$ Su correspondencia refleja sus necesidades y expectativas de enriquecimiento. Así en abril de 1702, escribía al marqués de Torcy, encargado de las Relaciones Exteriores francesas, pidiéndole su intercesión para que se le exonerara de las 20.000 libras de media annata del título de Grandeza y se le señalara un fondo competente para el sostén de su casa o en su defecto que se le asignaran algunos de los bienes confiscados o los cargos de Consejero de Estado y de virrey del Perú, donde pudiera aumentar su magro patrimonio, vinculándolo a un mayorazgo

“creo según lo que he oído siempre; ajenziar justamente algún caudal con lo qual a la buelta, si yo fuera tan dichoso que lo lograse podría fundar alguno que me redituase la maior parte, u el todo de lo que mi casa necesita". ${ }^{20}$

En junio de 1702 notificaba a su agente en Madrid, Pedro Arados Balmaseda, su nombramiento como virrey del Perú y le confesaba sus limitaciones políticas y sus ambiciones crematísticas, casi premonitorias de lo que le deparaba el destino

"yo se muy poco o nada de Indias... y espero lograr la misma fortuna según lo acostumbrados exemplares de otros". ${ }^{21}$

Su paso por España camino al Perú, y sobre todo la espera en Cádiz, se prolongó mucho más de lo previsto, desde mediados de 1703 hasta febrero de 1706, en una difícil coyuntura bélica, caracterizada por la toma de Gibraltar por los ingleses en 1705, el avance portugués sobre Extremadura y el levantamiento de Cataluña y en otros territorios de la Corona de Aragón como Valencia y Aragón, a favor del partido austriacista. Según su propio testimonio, fue un tiempo dominado por la "melancolía" y la inseguridad naval; mientras tanto las órdenes de salida de la flota se desdecían un día sí y otro también. Castelldosrius dejó en el trayecto de

19 AHNC, FMC, 1212.17. Relación de los daños excesivos que ha padecido el Mayorazgo del Exmo. Señor Marques de Castelldosrius en las Guerras que empezaron el año de 1705, sin hazer mención de las antepasadas. Barcelona, 23 de marzo de 1717.

20 AHNC, FMC, 1241.15.179. Carta del marques de Castelldosrius al Marqués de Torcy, París, 26 de abril de 1702.

21 AHNC, FMC, 1241.15.10. Carta de Manuel de Sentmenat a Pedro Arados Balmaseda, París, 18 de junio de 1702. 
su viaje por Madrid, Cádiz, Panamá y en los primeros meses en Lima, un largo rastro de empréstitos, muchos pactados a corto término, entre otros con la Compañía del Asiento de Negros, ${ }^{22}$ Bartolomé Flon y Mr. De Muves, ${ }^{23}$ Humberto de Hubrecht, ${ }^{24}$ vinculados a las fuentes de financiación o a intereses económicos de la monarquía borbónica.

En conjunto, su avidez económica pesó como una losa en su actuación en el Perú. Diversos sectores criollos le vincularon pronto a los intereses del comercio francés, en el que intervino a través de su hombre de confianza en Lima, Antonio Marí, catalán como él, un hecho que ha sido destacado en los estudios de G. Walker ${ }^{25}$ y C.D. Malamud. ${ }^{26}$

Sus detractores lograron incidir en la Corona, le acusaron de mantener fuertes intereses con el comercio francés, de corrupción en la provisión de cargos - a favor de sus allegados y de los mejores postores- y en las costumbres. En tal sentido no se cansaron de difundir que se pasaba el tiempo en comedias, fiestas, músicas o cazando en la chacra del marqués del Villar del Tajo o que "se hazia pagar sus versos a collares de Perlas". ${ }^{27}$ Fue un espectador apasionado de los conciertos en las porterías de los conventos, que mantenían su vigencia a pesar de su prohibición. Un hecho que se convirtió en un arma arrojadiza utilizada por sectores eclesiásticos en su contra y en uno de los cargos de su juicio de residencia, como prueba de que abandonaba por sus diversiones el gobierno del Perú.

Tal fue la capacidad de maniobra del partido opositor, en buena medida con fuertes intereses criollos, que lograron que Felipe V le destituyera, en un momento en torno a 1708-9, que coincidió con la pérdida de influencia del partido francés en la corte, a raíz del segundo matrimonio del rey con Isabel Farnesio. Gracias a la habilidad de sus agentes en Madrid -el cura Joseph Ruiz Cano, Antonio d'Oms (miembro del Consejo de Indias)

22 AHNC, FMC, 1242.19.382. Carta del Comte de Pontchertrain, Versailles, 22 de julio de 1703; 1242.19.403. Carta del Marques de Rivas, Madrid, 14.09.1703. El marques de Rivas prometía interceder a Luis XIV a través del cardenal Estrees.

23 AHNC, FMC, 1242.19.186. Carta de Bartolome Flon al marqués de Castelldosrius, Madrid, 7 de julio de 1704; 1242.16.6. Carta de Camus de Beaulieu a Josep de Sentmenat i d'Oms, París, 22 de noviembre de 1721 .

24 AHNC, FMC, 1242.19.221. Cartas de Humberto de Hubrecht, Madrid, 18 y 20 de julio de 1704.

25 Walker, Geoffrey J.: Política española y comercio colonial; 1700-1789. Barcelona, Ariel, 1979.

26 Malamud, Carlos D.: Cádiz y Saint Malo en el comercio colonial peruano, 1698-1725. Cádiz, Diputación Provincial, 1986.

27 AHNC, 1242.19.424. Carta de Joseph Ruiz Cano al marqués de Castelldosrius, Madrid, s.f., por los datos aportados de fines de 1709 . 
y su hija Catalina - logró pactar su continuidad en el cargo, más la prórroga legal, a cambio de un donativo a la Corona de 150.000 pesos. Sin embargo, no pudo cumplir el acuerdo ya que sólo logró disponer en Madrid de la dote que había remitido desde el Perú para su hija Catalina, sin que se lograra cubrir un empréstito de 100.000 pesos, lo que frustró su prórroga por cinco años en el gobierno del virreinato. ${ }^{28}$ Mientras se escenificaba su traspiés político y antes que los lentos correos navales le informaran de su cambio de fortuna, moría en Lima, en los primeros meses de 1710.

Su breve gobierno no dio tiempo para escribir la memoria oficial preceptiva, ni ha merecido un estudio global de su política. Se le ha vinculado al comercio - conflicto con el Consulado, intereses en el comercio francés-y se le ha señalado como un hombre que introdujo innovaciones considerables en los gustos y costumbres limeños. Sus contemporáneos testimoniaron que disociaba su tiempo, dedicando el día a los negocios y la noche a las actividades artísticas.

Louis Feuillé dejó en su diario de viaje una viva imagen del ambiente cultural de la Lima de 1709, auspiciado por el propio virrey

"Ce Viceroy etoit çavant, jamais les Sciences n'avoient fleuri dans le Perou avec plus d'éclat que durant son regne. Son Palais à Lima etoit devenu une Académie, \& les recompenses qu'il donoit aux Sçavans excitoient les esprits les plus delicats a produire presque tous les jours des ouvrages de leur façon. Les uns travailloient à la Physique, les autres aux mathematiques, d'autres s'occupoient à la Poësie, les Sciences \& les Arts commençoit déja a faire en cette Ville beaucoup de progrez" ${ }^{29}$

El marqués de Castelldosrius habría importado al Perú una forma de cotidianeidad cortesana, de sociabilidad y diversas experiencias culturales que tenían por entonces un papel destacado en Europa y que intentaré analizar.

\section{La corte del marqués de Castelldosrius}

El numeroso séquito de Castelldosrius, de procedencia diversa, pero con un alto número de franceses e italianos, fue uno de los elementos cla-

28 AHNC, 1242.19.424. Cartas de Joseph Ruiz Cano al marqués de Castelldosrius, Madrid, s.f. trunca y de 10 de febrero de 1710 .

29 Feuillée, Louis: Journal des Observations Phisiques, mathematiques et botaniques faites par l'ordre du Roi sur les costes orientales de l'Amerique Meridionale... despuis l'anné 1707 jusques en 1712. Par le R.P. Religieux Minime... París, 1713, 2 v., pág. 399. 
ve en su intento de imponer una cultura política cortesana en la Lima que estrenaba el largo y complejo setecientos. Su relación y sus avatares nos permitirán entender en cierta forma las relaciones y obligaciones que un funcionario y noble como Castelldosrius tuvo y quiso asumir.

Obtuvo sendas Reales Cédulas de 12 de marzo y 1 de abril de $1705^{30}$ que le autorizaban a viajar con sus dos hijos, Félix y Juan Manuel, un capellán, 48 criados y 12 criadas. ${ }^{31}$ Su desorbitado séquito o familiares, le plantearon sin embargo problemas con la Casa de Contratación. Su fiscal argumentó que siempre se había limitado a los virreyes y gobernadores que pasaran a sus cargos con familias numerosas; además, en su caso, si le acompañaban 30 franceses, cabría suponer que irían otros tantos españoles "que cause no poco escándalo y extrañeza en Lima, la imposibilidad de mantenerles de los frutos del virreinato", por lo que "se habrá de sugetar para utilizarlos a condescender a muchas de las proporciones de sus industrias", y mostraba la pena que le daban los franceses, porque no podría ofrecerles cargo alguno y sólo mantenerles como familiares, mirados con recelo por los comerciantes que temerían su competencia. ${ }^{32}$

Tal oposición, motivo que el futuro virrey buscara la intercesión del embajador francés, Amelot, quien debió dar una orden expresa para que se concediera al fin la autorización. ${ }^{33}$ Logró licencia para que se desplazaran al Perú: Ramón Tamarit y Sentmenat, natural de Perpiñán, Antonio de Santo Domingo, Martigny, Roustan, Antonio de Rosmain, Chamtd, Esteban Roulier, de Lisle, de Barmont, de Roquemont, de Louches, Bennal; dos pajes, M. Juan Baptista de Pierre de la Presa y Antonio Bautista de Daribal; dos ayudas de cámara, Duval y Dubois; el cirujano Tapier; tres músicos, Roque Cerutti y Binet y Clinet; dos reposteros, La Ferte y Alejandro Guillermo; cuatro cocineros, Nail, Gurlade, Fleuri y Juan Borgoña y cinco lacayos, Joseph Guichard, Diego, Pinar, Le Roy, Le Tover. ${ }^{34}$

La pronta partida de un nuevo alto funcionario a Indias era una de las grandes ocasiones para poder lograr embarcar como familiar o para obte-

30 AHNC, FMC, 1261.4.13. Licencia concedida por el Rey, Madrid, 1 de abril de 1705.

31 Se cita a los criados José de la Cueva, Juan Ibañez, Manuel Zarate y Miguel Busso, con sus mujeres, 12 gentiles hombres franceses, 2 pajes, 2 ayudas de cámara, un cirujano, 2 músicos, 2 reposteros, 4 cocineros, 5 lacayos. AGI, Contratación, 5463, N 43. Expediente de información y licencia de pasajero a Indias de M. Castelldosrius, inicio 5 de marzo de 1706.

32 AGI, A. Lima, 345, Consulta al Consejo de Indias e informe fiscal, 11 de febrero de 1705.

33 AHNC, FMC, 1241.15.8. Carta de Manuel de Sentmenat a Monsieur Amelot, embajador de Francia, Cádiz, 28 de febrero de 1706.

34 AGI, Escribanía de Cámara, 548, RC de 12 de marzo de 1705. Contratación, 5463, N.43. En 5 de marzo de 1706 se le concedía licencia para que embarcara con 30 personas. 
ner un primer destino en Indias, que fuera el inicio de una larga carrera. No es de extrañar que Castelldosrius recibiera un sinnúmero de cartas en que se le encomendaba tal o cual familiar o amigo. Intentaré describir ese entramado de mecanismos de recomendación.

El marqués de la Mina le rogaba tomara a su servicio a Don Miguel Antonio Bañuelos. ${ }^{35}$ Agustín de Robles le pedía que favoreciera a su sobrino el capitán Manuel de Robles "que pasa a su sombra a servir el Gobierno del Paraguai". ${ }^{36}$ El Duque de Gandía le recomendaba en 1704 a Elicio Teresi para que pasara a Indias como familiar del marqués. ${ }^{37}$ Diego Francisco de Echarri Garro y Xavier Tudela le pedían incluyera entre sus familiares a dos de sus hijos. ${ }^{38} \mathrm{El}$ Condestable logró que admitiera de paje a don Francisco de la Torre, del que decía era su ahijado e hijo de criados y vasallos. ${ }^{39}$

Desde la Corte francesa o por orden real le llegaron diversas peticiones, que podemos pronto comprender que serían muy difíciles de no atender. Destacaré la del Mariscal Duc de Noailles para Mr. de Roquemont. ${ }^{40}$ Las referidas a Antonio de Santo Domingo, segundo gentilhombre, incluidas en cartas del marqués de Rivas ${ }^{41}$ Fernando de Moncada, duque de Montalto y Príncipe de Paterno, ${ }^{42}$ conde de Monterrey, ${ }^{43}$ Claudio de la Roche, ${ }^{44}$ Condestable ${ }^{45}$ y del embajador Amelot, quien matizaba que aún siendo gentilhombre francés, su origen era español, habiendo el rey "fait la grace de l'honnorer d'un de les ordres, et le nommer pour accompagner VE aux Indes". ${ }^{6}$

Antonio de Ubilla y Medina le adjuntaba una R.C dada en Luzara el 2 de setiembre de 1702, por la que se concedía licencia a Esteban Roullier

35 AHNC, FMC, 1242.19.298. Carta del marques de la Mina, Madrid, 12 de febrero de 1706.

36 AHNC, FMC, 1242.19.409. Carta de Agustín de Robles, La Laguna, 12 de mayo de 1705.

37 AHNC, FMC, 1242.19.198. Carta del Duque de Gandía, 22.?.1704.

38 AHNC, FMC, 1242.19.158. Carta de Diego Francisco de Echarri Garro y Xavier Tudela, 17 de setiembre de 1704 .

39 AHNC, FMC, 1242.19.121. Cartas del Condestable, Madrid, 26 de mayo de 1705 y 18 de febrero de 1706.

40 AHNC, FMC, 1242.19.326. Cartas del Mariscal Duc de Noailles, Versailles 1 de agosto de 1704 y 10 de agosto de 1704 .

41 AHNC, FMC, 1242.19.403. Carta del marques de Rivas, Madrid, 17 de febrero de 1706.

42 AHNC, FMC, 1242.19.301. Carta de Fernando de Moncada, Madrid, 16 de febrero de 1706.

43 AHNC, FMC, 1242.19.306. Carta del Conde de Monterrey, Madrid, 18 de febrero de 1706.

44 AHNC, FMC, 1242.19.411. Cartas de Claudio de la Roche, Madrid, 18 de febrero de 1702 y 1706.

45 AHNC, FMC, 1242.19.121. Cartas del Condestable, Madrid, 26 de mayo de 1705 y 18 de febrero de 1706 .

46 AHNC, FMC, 1242.19.44. Carta de Amelot, Madrid, 19 de febrero de 1706. 
para que viajara a Indias y se le diera cualquier ocupación. ${ }^{47}$ También le pedía su protección el marqués de Rivas por "ser hijo de la Ama que sirvió al Rey", al que se le pedía "atienda con toda especialidad, favoreciéndole en lo que se le ofreciere" ${ }^{48}$ Éste insistía en 1706 a favor de Francisco Pérez de la Torre y Zuñiga, quien servía de paje del marqués de Castelldosrius, de cuya familia se decía tener obligaciones, para que "facilite a mi encomendado toda la fortuna que yo le deseo". ${ }^{49}$

Juan Baptista de Rosmain era ingeniero ${ }^{50}$ y le fue asignado por el propio Luis XIV, "para disponer las mejores reglas a las fortificaciones que se hayan de ejecutar en las Yndias", con orden de Felipe V de que se le pagara el sueldo más conveniente desde su llegada a Cádiz hasta su vuelta a España o a Francia. ${ }^{51}$ Sin embargo no fue fácil obtener el permiso definitivo para su pase a América, lo que muestra cierta tensión entre el Consejo de Indias y determinadas medidas tempranas de Felipe V. Así el Consejo de Indias respondió a la consulta del rey que ya existían ingenieros en Veracruz, La Habana y Tierrafirme, además de otros ingenieros franceses que habían salido a Indias, por lo que aconsejaban que no siguiera viaje. Se mostraron partidarios del traslado al Perú de don Melchor Vélez de Guevara, miembro de la expedición del Darien o el Sargento Mayor Juan de Herrera, encargado de planificar las fortificaciones de La Habana. En cualquier caso, si se persistía en la intención de destinarle al Perú, consideraron que debía limitarse la facultad concedida a Castelldosrius para fijar su sueldo, en el sentido de que no podía exceder los fijados por entonces a los otros ingenieros de Indias. ${ }^{52}$

Distintos testimonios coetáneos traslucen una corte que fue incapaz de comprender la sociedad peruana de aquel entonces, en especial la limeña que conocieron. Es posible que cayeran presos y deslumbrados por la imagen preconcebida del Perú como una suerte de Dorado o de vaca cuyo odre se podría exprimir sin fin, para situarles a su vuelta en la Corte de Luis

47 AHNC, FMC, 1242.19.513.

48 AHNC, FMC, 1242.19.403. Carta del marqués de Rivas, Luzara, 15 de setiembre de 1702. La propia madre de Roulier se lo recomendaba en 1705, en 1242.19.49.

49 AHNC, FMC, 1242.19.403. Carta del marqués de Rivas, Madrid, 2 de febrero de 1706.

50 Sirvió como ingeniero en la campaña del País Valenciano y Andalucía. AHNC, FMC, 23 de agosto de 1705. Cartas de Rosmain, Malaga 23 y 29 de agosto de 1705.

51 AHNC, FMC, 1242.19.73. Carta del Rey, Madrid, 14 de agosto de 1705.

52 AGI, A.Lima, 345. Consulta al Consejo de Indias relativa al sueldo que debía gozar Monsieur de Rosmayn, 11 de setiembre de 1705. Los sueldos variaban, el de Valdes era de 116 escudos mensuales, Herrera 80 escudos sobre la renta de almojarifazgo, Rochefort 100 escudos más el alojamiento. 
XIV con la brillantez con que soñaban. El virrey fue consciente de ello y de los problemas que podía acarrearle su desencanto, cuando rotas sus espectativas, algunos de ellos optaron por regresar a Europa a la primera oportunidad que tuvieron. Según Castelldosrius Monsieur Rollier hacía el tornaviaje incapaz de esperar mejor suerte, debido a su genio, "tan ligero y fácil como se save y no haver podido parar en ninguna parte", a más de mostrarle cierta desconfianza; La Pressa se iba para tomar posesión de una herencia; don Esteban de Ruytan, teniente de la guardia de Arqueros, volvía a raíz de una disputa con su hijo por "algunas dependencias de intereses"; Clinet, músico de violón, despreciando su sueldo anual de 560 reales; Martigni arguyendo su malestar en Lima

"donde se come y beve mal, y se divierte peor, circunstancias para el, imposibles de practicar"

y el sentirse desairado por los hijos del marqués que se negaron a llevarle en su coche; Santo Domingo, quien unas veces se hacia pasar por español y otras por francés, para defender su derecho a ocupar cargos en la administración colonial, jugador empedernido y prendido de una "veleydad nativa", abandonó el puesto de Procurador de Valdivia — con un valor estimado en más de 1.200 reales cada año- por no serle suficiente.

El virrey les daba en parte la razón porque Perú, en sus palabras, "es muy diferente para la vida bona de el suyo". Sin embargo consideraba que no podían quejarse o llevarse a engaño, ya que sabían antes de su partida de Francia y España que les sería imposible alcanzar oficio alguno por su condición de extranjeros, y que él mismo, aunque quisiere contentarles, tenía primero que acomodar a los "Conquistadores" y luego a sus criados de mayor antigüedad..$^{53}$

Preocupado por el caso de Martigni en lo que pudiera afectar sus propias relaciones cortesanas, el virrey escribió en noviembre de 1707 a la Princesa d'Epinoy indicándole que no había podido concederle ningún cargo por las prohibiciones vigentes, pero había pesado en su decisión final el hecho de no haberse adaptado al país, "d'ailleurs le pais qu'il na pas trouvé trop favorable a sa sante". En similares términos se dirigió a la duquesa de Ledediguiesec, al duque de Borgoña, al de Be-

53 Lohmann Villena, Guillermo: "El 'Cuadernillo de noticias' del virrey del Perú marqués de Castelldosrius (Agosto 1708)". Jahrbuch für Geschichte von Staat, Wirtchaft und Gesellschaft Lateinamerikas, 1964, págs. 207-237. 
rry $^{54}$ y lo recomendó al conde de Tolosa, informándole que no había podido darle ningún puesto por ser francés. ${ }^{55}$

Lo antedicho nos muestra una compleja trama de intereses, en un mundo en que para casi todos la divisa era conjugar el verbo deber, insertos en una red de relaciones que se establecían entre iguales y con subordinados. Castelldosrius tuvo poca capacidad para maniobrar en una Lima que detestaba a los extraños, sobre todo si estaban vinculados a Francia, vista como origen de parte de los males que padecía la élite comercial vinculada al Consulado.

\title{
La escenificación urbana del poder: Fiestas, celebraciones, poesía, música, teatro
}

La literatura puesta al servicio de la política y para ensalzar el papel destacado ejercido por el marqués discurre por toda su trayectoria de funcionario en los diversos puestos en la administración estatal, pero cobra especial relevancia desde sus puestos de embajador en Lisboa y París. Se conserva una elegía redactada en francés en conmemoración a su despedida de Francia ${ }^{56} \mathrm{y}$ reproduzco parcialmente la que fue impresa en castellano en 1701

\author{
Vais a partir la autoridad de los Príncipes \\ vais a mandar ocho veses diez Provincias, \\ vais a ocupar, el lugar de un gran rey, \\ en vastos climas, cometidos a vuestra fe. \\ el Perú, con todo el oro, que produce y junta \\ reúne sus tesoros, y os los ofrece juntos. \\ rico en honores, en gloria, en verdaderos títulos antiguos, \\ os veréis en fin, también rico, en muchos bienes. \\ la Fortuna os colma y su mano liberal, \\ en bienes, como en poder, a los Cresos, os iguala.
}

54 AHNC, FMC, 1241.15.57. Cartas de Manuel de Sentmenat a la Princesa d'Epinoy, a la duchesse de Ledediguiesec, Mde La Princesse d'Epinoy, Callao, 12 de noviembre de 1707; 1241.15 .76 al Delphin, Lima, 27 de diciembre de 1707.

55 AHNC, FMC, 1241.15.178. Carta de Manuel de Sentmenat al conde de Tolosa, Callao, 12 de diciembre de 1707.

56 AHNC, FMC, 1261.3.9. Elegie sur le depar de Son Exc Monsieur le Marquis de Castel dos Rios, Grand d'Espagne, du Conseil de guerre de S.M.C. Ambassadeur en France, cy-devant Viceroy de Mayorque, \& Ambassadeur en Portugal, nommé à la Viceroyauté du Perou. S.f. 
que el Moro, desecho hizo tomas a vuestros Abuelos defensores de sus reyes, y vengadores de sus amos assi fueron esos héroes, assi fueron vros antepasados $\cdots$ diréis algunas vezes manando en la opulencia la España me debe todo, yo devo todo a la Francia Yo devo todo mi honor a mi ultimo empleo ${ }^{57}$

Su llegada a Lima no podía ser ajena a su trayectoria personal, aunque fue fiel al protocolo vigente en la ciudad de Los Reyes. El ciclo festivo colonial se hallaba marcado por las conmemoraciones y aniversarios de la familia real, el recibimiento de un nuevo virrey y las celebraciones religiosas. En la primera década del siglo XVIII, los objetivos fueron reforzar la imagen pública de la nueva dinastía y del primer virrey borbónico, sin que perdieran protagonismo las fiestas religiosas, en las que resaltaba el creciente arraigo de las advocaciones criollas.

El 7 de julio de 1707 se escenificó el traspaso de poderes de la Audiencia al nuevo virrey. J. Bromley no apunta ninguna innovación en el ceremonial, señala que el pregón requería que se barrieran las calles y se iluminara la ciudad y las casas del Cabildo. Se enviaron invitaciones a las distintas instituciones limeñas y se convocó a todos los capitulares para ir a su recibimiento al Callao. ${ }^{58}$ Sin embargo había desembarcado en Payta, permaneció durante la Semana Santa en Trujillo y siguió su trayecto a Lima en calesa, llevada en brazos en los malos pasos del desierto y ríos costeños. Llegó al Callao el 13 de mayo, donde esperó cinco o seis días, tras los cuales entró de incógnito a Lima a la espera de que se organizara su entrada pública el 7 de julio en honores y vítores. A pesar de mostrarse encantado por el clamor de su recibimiento, escribiría al rey premonitoriamente "quiera Dios que para la salida nos guarde algo de lo que entonces expresaron los afectos universalmente de ellos". ${ }^{99}$

57 AHNC, FMC, 1261.3.8. A su excelencia el Sr. Dn. Manuel d'Oms y de Santa Pau, Sentmanat y Lanuza, Marqs de Castelldosrius del Consejo de Guerra de su Magd Catolica, virrey que fue de Mallorca, y su embaxr en Portugal, actualmente embaxador en Francia... por su mui humilde y obede señor O.M. Manuscrito, permitido imprimir en 23 de enero de 1701. Existe una copia impresa en francés, Signé de Voyer d'Argenton.

58 En realidad los actos se ajustaron al protocolo al uso, en tal sentido ver Biblioteca de Cataluña, Manuscrito 205, Sobre etiqueta y ceremonial que esta en uso al ingreso de los Sres. Virreyes. Don Alvaro Navia Bolaño, Lima, 25 de junio de 1747.

59 AHNC, FMC, 1241.15.25. Carta del marqués de Castelldosrius al Rey, Lima, 2 de setiembre de 1707 . 
La Universidad de San Marcos organizó, como de costumbre, un certamen poético. ${ }^{60}$ De él existen dos textos impresos, uno editado en Lima en 1707, Triunfal aclamación ${ }^{61}$ que J. A. Rodríguez atribuye a Pedro Joseph Bermudez de la Torre y Solier, conservado en el fondo de los Marqueses de Castelldosrius y el recopilado al año siguiente por Pedro Peralta y Barnuevo en Lima triumphante. ${ }^{62}$ Tres fueron los temas poéticos propuestos en la Universidad, "los doce cisnes que, según anuncio de Venus a Eneas, indicarían la llegada a puerto feliz; las doce palmas que adornaban el escudo de Castelldosrius y las doce facultades que componían el claustro universitario", lo que, según J.A. Rodríguez, mostraría un plan que armonizaba la poesía, lo intelectual y el poder ${ }^{63}$ En su opinión, "se trazaba una continuidad que partía de los orígenes de la monarquía española y concluía en el ámbito del saber universitario peruano, y la presencia del Virrey se presentaba como vínculo a través del cual los intelectuales del virreinato se insertaban en la gran historia imperial". Las artes y el saber eran vistas como mecanismos que permitirían el futuro dominio político, tanto de Castelldosrius, como de los intelectuales sanmarquinos. ${ }^{64}$ En opinión de J.A. Rodríguez, "Peralta elabora un marco con una clara intención política, que constituye una velada y cauta declaración del derecho de las elites letradas limeñas a participar en las estructuras del poder", ${ }^{65}$ en el recibimiento de un virrey. J.A. Mazzotti ha señalado como Pedro Peralta Barnuevo caracteriza en esta obra a Lima y sus habitantes criollos como

60 Bromley, Juan: "Recibimientos de Virreyes en Lima”. Revista Histórica, Lima, Instituto Histórico del Perú, 1953, t.XX, pp.93-94.

61 Triunfal aclamación, festivo obsequio y poético certamen que consagra reverente y afectuosa la Real Universidad de San Marcos de la ciudad de Lima, corte del Perú, al Excmo. Señor Don Manuel Oms y de Santa Pau, olim de Sentmanat y Lanuza, marqués de Castelldosrius, Grande de España, del Consejo Supremo de Guerra, Virrey, que fue, del Reyno de Mallorca, y ahora destos Reynos del Perú, Tierrafirme, y Chile \&c. Con licencia en Lima. Por Joseph de Contreras y Alvarado Impressor Real. Año 1707.

62 Peralta y Barnuevo, Pedro de: Lima triumphante, glorias de la América, Juegos Pythios, y jubilos de la Minerva peruana en la entrada que hizo s.exc. en esta muy noble, y leal ciudad, emporio y cabeza del Perú, y en el recibimiento con que fue celebrado por la Real Universidad de Sn Marcos. Consagralas a S. Exc. Por las mismas escuelas el Dr. D. Isidoro de Olmedo y Sossa, su Rector publícalas el Dr. D. Pedro Joseph de Peralta. Al Excmo Señor D. Manuel de Oms y de Santa-Pau Olim de Sentmenat y de Lanuza, Marqués de Castelldosrius, Grande de España, del Consejo Supremo de Guerra, Virrey que fue del Reyno de Mallorca, y ahora destos del Peru, Tierrafirme y Chile \&C. Lima, por Joseph de Contreras y Alvarado, 1708

63 Rodríguez, José A.: "La voz de las repúblicas": poesía y poder en la Lima de incios del XVIII". En: Mazzotti, J. A. (ed.): Agencias criollas. La ambigüedad “colonial” en las letras hispanoamericanas. Madrid, Iberoamericana, 2000, pág. 252.

64 Rodríguez: “La voz...”, pág. 250.

65 Rodríguez: “La voz...”, pág. 254. 
una Ariadna mal retribuida por el Teseo español. ${ }^{66} \mathrm{Y}$ si bien se ha destacado el criollismo de Peralta, debemos recordar que mantuvo una posición en cierta forma afrancesada, como lo muestran sus obras Le triomphe d'Astrée y La glorie de Louis le Grand, destinadas a elogiar a Felipe V y su abuelo, Luis XIV.

En el certamen poético ofrecido por la Universidad a su llegada, participó su mayordomo, Rafael Masferrer, con la siguiente poesía

CASTEL, que de Dos Rius estan bañat

A Parais deixant li els altres Dos

Sempre Fort, sempre Antic, sempre Glorios

Tant manant Mils, com fent, de bent-Menat

En vos, tan solament he reparat,

Lo que no podrà dir altre dichos,

(Lladre, mes que la enbidia de algun gos)

De Dotse Palmes sempre coronat

Os veis CASTELL, y RIUS, en totes parts

$\mathrm{Si}$ a Franza vais, si vaig a Portugal,

Regnes, ù de Mallorca, ù del Perú.

I a de la Guerra sobraran los Arts

Uent un CASTELL, que lliura de tot mal,

Sent en qualsevol Regne, sempre ù. ${ }^{67}$

Le acompaña la anotación "por ser el Acrostico en lengua Lemosina lo fue tambien el SONETO", que en general ha sido reproducida textualmente, sin considerar que no era Lemosin, sino catalán, la lengua materna de Masferrer como del virrey. Una muestra más de la necesidad de comprender que el certamen poético sanmarquino, que permitió editar en Perú la primera poesía documentada en lengua catalana, fue una suerte de reivindicación del pluralismo cultural de la Monarquia Hispánica, en la que se conjugaron el hispanismo y el criollismo, junto con la cultura catalana.

66 Mazzotti, José Antonio: "Resentimiento criollo y nación étnica: el papel de la épica novohispana”. En: Mazzotti, José Antonio: Agencias criollas: La ambigüedad colonial en las letras hispanoamericanas. Madrid, Iberoamericana, 2000, págs. 143-160.

67 CASTILLO (CASTELL), que de Dos Rios (Rius) esta bañado/ Aparece dejando le los otros Dos/ Siempre Fuerte, siempre Antiguo, siempre Glorioso/ Tanto mandando miles, como haciendo, de bienmandado/ En vos, tan solo he reparado/ Lo que no podra decir otro dichoso/ Ladrón, más que la envidia de algún perro/ De doce Palmas siempre coronado/ Os veis CASTILLO y RIOS, en todas partes/ Si a Francia vais, si voy a Portugal/ Reinos, o de Mallorca, o del Perú/Y de la Guerra sobraran las Artes/ Viendo un CASTILLO, que libra de todo mal, / Siendo en cualquier Reino, siempre uno [Traducción propia]. 
Varias preguntas surgen de la existencia de dos ediciones del certamen poético, separadas por un año. ¿Tal fue su éxito? $\mathrm{O}$ ¿cuál fue su interés o conveniencia? Y, por otro lado, ¿que información añadió Peralta sobre Castelldosrius? Quisiera hacer notar el hecho que Peralta, ${ }^{68}$ un hombre polifacético y de cultura amplísima, dedicara varias de sus obras a elogiar a los virreyes peruanos o ha redactar sus memorias por encargo de éstos, una serie que empieza con Lima triumphante (1708) y continua con El templo de la fama vindicado ${ }^{69}$ (1710), la Imagen política (1714) del gobierno de Diego Ladrón de Guevara (1710-16), obispo de Quito, el Cartel del certa$m e n^{70}$ en honor del virrey Fr. Diego Morcillo (1716, 1720-24), la memoria de gobierno del virrey marqués de Castelfuerte (1724-1736). ${ }^{71} \mathrm{O}$ una serie de textos de tema histórico y reivindicativo, como su Historia de España vindicada ${ }^{72}$ (1730), las dedicadas a Lima $^{73} \mathrm{o}$ a narrar el auto de fe de $1733 .^{74}$ Textos que merecen un atento análisis como fuente histórica, pero de los que quiero destacar una voluntad, por parte de su autor, de devenir una suerte de cronista peruano, en un proyecto que le vinculaba a los vaivenes del poder.

Lima triumphante apareció editada en 1708, el año en que Castelldosrius vió como se organiza en su contra una oposición criolla consistente, al punto que varios de sus adversarios viajaron a España para influir en el rey y en lograr su destitución. Recordemos que se le acusaba de ser hombre disoluto, de no haber celebrado suficientemente el nacimiento del Príncipe, de connivencia con el comercio francés y de venalidad, en su beneficio y de sus familiares, en la concesión de cargos públicos. En paralelo se fueron resquebrajando sus alianzas con los franceses, tanto por su incapacidad para reintegrar sus préstamos personales, como en la misma corte,

68 Un balance de conjunto sobre la obra de Pedro Peralta Barnuevo en Sánchez, Luis Alberto: Doctor Oceáno. Lima, 1967.

69 Peralta y Barnuevo, Pedro de: El templo de la fama vindicado. Discurso escrito por el en honor del Excmo. Señor D.Fr. Diego Morcillo. Lima, por Francisco Sobrino, 1710.

70 Cartel del certamen. El theatro heroico. Certamen poetico que ofrece, dedica y consagra amante, obsequiosa, y reverente la real universidad de San Marcos de esta ciudad de Lima... al excelentisimo señor don fr. Diego Morcillo Rubio de Auñon. Lima, 1720.

71 Moreno Cebrián, Alfredo: El virreinato del marqués de Castelfuerte...pág.338-9.

72 Peralta y Barnuevo, Pedro de: Historia de España vindicada. En que se haze su mas exacta descripción la de sus excelencias, y antiguas riquezas. Lima, Francisco Sobrino, 1730.

73 Peralta y Barnuevo, Pedro de: Lima fundada. O conquista del Perú. Poema heroico. Lima, Francisco Sobrino y Bados, 1732 y Lima inexpugnable.

74 Peralta y Barnuevo, Pedro de: Relación del auto de fe celebrado por el Sagrado Tribunal del Santo Oficio de la Inquisición de estos Reynos en la muy noble y leal ciudad de Lima... en el día 12 de julio del año 1733... Lima, Por Francisco Sobrino, 1733. 
sensible a las críticas de cuantos vieron rotas sus expectativas de beneficios comerciales en el Pacífico o como miembros de la corte bajo la autoridad virreinal. El duque de Alba, embajador en París, se hacía eco de ello en una carta de agosto de 1710 al referirle que sus intereses "me han hecho ser broquel contra tanto enemigo como se unió para obscurecer tu obra". ${ }^{5}$

El embajador francés en España, Amelot, era más explícito en carta a Luis XIV, y situaba las raices de su descontento con Castelldosrius dentro de un marco general de la política colonial hispana

"Las riquezas de Perú y México, aquellas inagotables fuentes de riqueza, se han perdido casi por completo para España. No sólo existen quejas contra los comerciantes franceses por arruinar el comercio de Cádiz y Sevilla, a pesar que las regulaciones de la corte francesa contra quienes infringen las normas establecidas, sino que siguen produciéndose, sin disminuir un ápice, los abusos de la administración de los virreyes. La avaricia y el pillaje no se castigan, las fortalezas y guarniciones se hallan en estado de abandono; todo parece presagiar una revolución fatal.

Hay que tomar decisiones para hacer regresar a los dos virreyes y para fijar algunos límites exactos a los beneficios de sus sucesores, de manera que tengan la posibilidad de enriquecerse sin dejar de cumplir su deber. Reconozco que el expediente no bastará para refrenar la avaricia, pero no creo que pueda existir otra medida mejor, aunque se apunte a personas muy distinguidas por su firmeza y probidad. Tan difícil resulta encontrar entre los aristócratas una mente lo suficientemente fuerte como para resistir la influencia del ejemplo y el interes". ${ }^{76}$

El análisis de Amelot apuntaba hacia lo que después sería uno de los ejes del Reformismo Borbónico, la urgencia de una reforma en la administración colonial que erradicara la corrupción y la ineficiencia, en el sentido de imponer un cuerpo de funcionarios probo, cuya divisa fuera la eficacia y que asegurara la reversión de las rentas coloniales a la Corona y a la economía española.

Podríamos, pues, considerar Lima triumphante como un texto de propaganda destinado a ensalzar al virrey con el recurso a un discurso historicista. Sus cuatro glorias o capítulos resumían la historia de la Monarquía española y el cambio de dinastía; el papel desempeñado por Castelldosrius como embajador en Francia en la sucesión al trono y su nombramiento como virrey; su llegada al Perú; y, por último, el recibimiento en la Universidad de San Marcos y el certamen poético en su honor. to de 1710 .

75 AHNC, 124219.8. Carta del duque de Alba al marqués de Castelldosrius. París, 25 de agos-

76 Carta de Amelot a Luis XIV de 1709, en: Coxe,W.: Memoirs of the Kings of Spain of the House of Bourbon, Londres, 1815, I, pág. 440, citado por Lynch, J.: La España del siglo XVIII. Barcelona, Crítica, 1999, págs. 56-57. 
La primera Gloria culminaba con una loa a Felipe V y a la nueva dinastía borbónica. La segunda gloria se dedicaba a la promoción del marqués de Castelldosrius al virreinato del Perú y la historia de su linaje. Un panegírico en el que se destacaba su papel en la sucesión al trono como embajador en Francia, no de los monarcas, sino de la monarquía, lo que supuso salvar una situación crítica y lograr

"Tener España Rey; quedar entera la Corona en la inmutable unión de 22 Reynos que la forman; y superar la pactada División, era el punto supremo, de que dependía su conservación, o su ruina".

Las viejas monarquías tenían, según razonaba Peralta, "sus años climatéricos, en que les suceden sus mudanzas", lo que era a la postre una forma organicista y cíclica de ver el devenir histórico. En premio a su papel, Castelldosrius recibió la Grandeza de España y el virreinato del Perú, "siendo mellizas ambas fortunas", de quien destacaba su nobleza

"Es la Nobleza una qualidad, que siendo lo más que se recibe, quando no puede usarse, es lo menos que se tiene, quando pudiendo, no se usa. Es una esphera de esplendor, en que se gradúan los hombres por elevación de sus acciones. Es por esto hija del mérito, madre del honor, y hermana de la inmortalidad"

Remontaba la nobleza de la familia de Castelldosrius a los Godos, que llegaron a Cataluña con Carlomagno, lo que le permitía afirmar

"Reconocer S.Exc. descendiendo del Augusto Ataulpho, el mismo origen que su Casa, que España para su Monarquía"

Obtuvieron privilegio del emperador Carlos V, Carlos de Oms y su hermano, Juan de Oms. Antepasados suyos defendieron "la Sagrada Pyxide de un bárbaro furor", o triunfaron sobre tres reyes moros - cuyas coronas pendían en su escudo para la posteridad—; Ramón de Sentmenat fue Camarero y Consejero de Estado del Rey D. Martín de Aragón, y Galcerán de Sentmenat le acompañó en la toma de Sicilia, por lo que fue armado caballero y premiado con el Estado de Peración; Juan de Sentmenat, que tomó partido por el rey don Juan II; Martín de la Nuza, participó en la batalla de Rubinat, por lo que Juan II le "divisasse su Armas con las Reales de Cataluña"; Ponce de Santapau, general de la Armada del rey Pedro IV de Aragón, quien actuó en la defensa de Cerdeña, de la que fue capitán general; Galcerán de Santa Pau murió en el cerco de Villaiglesias; Hugo de 
Santapau a quien el Rey concedió el Estado del Manfre de Alagón en Sicilia, tras participar en la campaña de Cerdeña; Bernardo de Oms, gobernador de los Condados de Rosellón y Cerdaña por Juan II de Aragón, quien murió en combate en Perpiñán, continuó en el cargo su hijo Luis de Oms, incluyendo la castellanía o alcaldía de la fortaleza de Perpiñán; Berenguer de Oms, general de Armada, que defendió Tánger del rey de Fez. No existía cargo de virrey, consejero, general y embajador que no se hubiera ejercido por su familia "tanto diestra en las ocurrencias de la Política, como en las arduidades de la Guerra".

He reproducido la larga sucesión de antepasados y sus méritos que son mencionados por Peralta porque no pudo narrar sus hechos y gestas, sin que Castelldosrius le suministrara la información precisa, por tratarse de datos, reales y legendarios, sobre una familia nobiliaria catalana y ser los sucesos históricos citados vinculados a la Corona de Aragón y su política medieval y moderna mediterránea y en lo que hoy es la Cataluña Norte, dominada por Francia luego del Tratado de los Pirineos. A pesar de su saber enciclopédico, Peralta no debía tener datos a mano que le permitieran por si sólo documentar la historia familiar de Castelldosrius. Estaríamos por tanto ante una narración historicista que pretendía ensalzar la figura de un virrey, inmerso en una coyuntura política difícil, que se servía de la literatura como arma de propaganda para mantener el poder.

La tercera gloria se dedicó a la entrada de Castelldosrius en Lima, "emporio de la América Austral", tras un largo viaje

"parecía que el viage de S.Exc. se havia hecho el de Ulysses, y que Lima se había transformado en Itaca"

que se había complicado por el conflicto naval con ingleses y holandeses, pero que había conseguido llegar a Lima, donde era ya tan amado como lo había sido en París y se situaba entre los grandes virreyes que la habían gobernado

"Quando un Chinchon me governo tranquilo, quando me influía un Guadalcazar, amor de todo el Reyno, y me ilustraba un Lemos memorable en la piedad; quando me adornaba con muros un Palata, me dirigía con Leyes un Toledo, me amplificaba con Edificios un Monclova, aun no me parecía tan dichosa, porque no era tuya"

Seguía un canto a la llegada del embajador de Castelldosrius, don Nicolás de Mansilla y Villavicencio, contador del Tribunal y Audiencia de 
Cuentas, "Iason ni Theseo volvieron a su Patria mas Gloriosos", pues sus noticias eran más preciosas que el vellocino de oro o que el hilo de Ariadna. La metáfora amagaba una realidad más prosaica, ya que en realidad Mansilla negoció, con el marqués aún en París y a través de su agente en Madrid, el puesto de embajador en 4.500 pesos, a pagar por mitad en Andalucía y Panamá. Un acuerdo mal cerrado, al que se sumaría que, a pesar que tenía título de corregidor de Aymaraes por la Real Audiencia de 21 de setiembre de 1702, el virrey le impusiera de corregidor interino a Juan Ibañez, uno de sus criados. Su desencuentro, le llevó a personarse como parte afectada en el juicio de residencia del virrey. ${ }^{77}$

Pedro Peralta se hacía eco de la decadencia de Lima y su gente, a pesar de que su nobleza descendía de la mejor de España y Castilla

\begin{abstract}
"Pero lo que el tiempo les aumenta de notoriedad, les quita la distancia de esplendor: pues sin el premio de las Encomiendas, y de los Oficios, que han sido las dos alas, con que hasta aquí volaba, gime en total desmayo. Y si es cierto, que son los Nobles los espíritus del corazón de la República, si estos le pierden, que medio haura para que no padezca fatal syncope su cuerpo?.
\end{abstract}

Un sentir expresado cuando arreciaban las críticas contra el virrey, que le motivaron a mandar a la península pliegos de descargos en el correo que compartía surcada con sus detractores. En ese coyuntura redactó el Cuadernillo de Noticias que remitió a su agente en Madrid, don Pedro de Arados Balmaseda. En el expuso sus diferencias con Chabert, el capitán del Aurora, barco francés que debía transportar caudales de emergencia para afrontar el conflicto bélico contra los austriacistas, y con parte de su clientela francesa; pero también con el Consulado de Comercio en la organización de la Feria de Portobelo y con quienes, a pesar de poseer títulos de corregidores, no les permitió tomar posesión de sus puestos, prefiriendo nombrar a interinos entre sus allegados o entre quienes pujaron por ellos. ${ }^{78}$

La documentación privada arroja luz para comprender a un Castelldosrius que confundía voluntariamente lo público con su peculio personal. Sus fuertes expectativas de ingresos extraordinarios, derivados, entre

77 Fue resultado de una larga negociación, entre una oferta inicial de 4.000 pesos y la exigencia por Castelldosrius del doble o al menos 6.000 pesos u otros 3000 doblones "para conducirse en la Corte de Madrid". AGI, Escribanía de Cámara, 548 (A). Juicio de Residencia del marqués de Castelldosrius. La compra-venta del cargo en carta del marques a Arados, fechada en París, adjunta al expediente.

78 Lohmann Villena, Guillermo: “El ‘Cuadernillo de noticias’... 
otros, de la venalidad de cargos, se desvanecieron, según su propia opinión o de su entorno, a causa de una situación de decadencia, ya que sólo había podido nombrar tres de los doce corregidores de concesión real, por el crecido número de futuras que existían,

"de que resulta tambien no solo la total falta de cortexos que antes heran corrientes, sino tambien la soledad continua de la antecamara de V.E. porque los que pudieran ser pretendientes que son los nobles de esta ciudad reconozen que aunque V.E. se compadeze de sus atrasos ni puede remediarlos, ni ellos conseguir la decencia necesaria para frequentar el Palacio como antes, por que siendo los oficios que davan los Sres Virreyes hasta sesenta se alternavan en ellos los Cavalleros, y podían parezer en público y seguir la Corte"

A lo que se añadía que las encomiendas también se estaban otorgando por la Corona a "sugetos de la Europa", en plena decadencia y finiquitas por falta de indios y por ello

"lo que los antecesores de V.E. pudiesen recoxer en obsequios, [h]an de ser para V.E. quejas." 79

El texto de Peralta en defensa de la nobleza y la preocupación del virrey buscaba entonces defenderse de los cargos del partido criollo y buscar la complicidad de la nobleza limeña, para tejer alianzas que le permitieran superar su declive político. No dejaban de ser sus próximos, con quienes compartía blasones y linaje. Se conservan varios documentos genealógicos que pueden datarse en la primeras décadas del s.XVIII cuando transcurre nuestra historia, que inciden en entroncar a los Castelldosrius con los godos ${ }^{80}$ Originarios de Alemania, participaron en la conquista de Asturias y Vizcaya, fijaron su "asiento y solar" en Cataluña. ${ }^{81}$ Entre sus antepasados se destaca a Ramón Berenguer que participó en la conquista de Cerdeña en 1323, a Galcerán, camaralengo en 1410 y el I marqués que destacó en las guerras contra Francia, en $1673,{ }^{82}$ y mostró su "innata fidelidad para con sus Reyes y señores" en los sucesivos cargos que ocupó, lo que le mereció la

79 AHNC, FMC, 1242.19.558. Carta anónima que puede atribuirse a Antonio Marí, fechada en De casa, 28 de diciembre de 1709 .

80 AHNC, FMC, 1211.1.4. Origen de la familia de Sentmenat Ethimologia de su nombre y noticia de sus Armas. S.f.

81 AHNC, FMC, 1211.1.6. Genealogía de la Ylustre Familia de Sentmenat con Memorias de sus gloriosos sucesos. S.f.

82 AHNC, FMC, 1211.1.6. Memorias chronologicas de la Nobilisima casa de Sentmenat en Cathaluña, sacadas de varios Archivos y Authores. 
Grandeza de España. ${ }^{83}$ Argumentos que coinciden con los esgrimidos por la nobleza catalana contemporánea, que remontaron sus orígenes míticos a linajes alemanes o franceses, en un tiempo en que la nobleza castellana se entroncaba legendariamente con los godos. ${ }^{84}$

Lima no fue ajena a las celebraciones de la nueva dinastía borbónica, como muestra la representación en 1701 de La púrpura de la rosa de Calderón, que J.A. Rodríguez considera que "pudo servir para legitimar, por medio de los símbolos teatrales, la idea de continuidad y renovación" que para algunos simbolizaba el cambio de dinastía ${ }^{85}$ Las victorias sobre los ejércitos austriacistas se celebraron al menos en $1706^{86} \mathrm{y}$ en marzo de 1707, en éste caso con máscaras, músicas y la representación de La fiera, el rayo y la piedra de Calderón de la Barca. ${ }^{87}$ El cumpleaños del monarca ocupó un lugar destacado, así el 19 de diciembre de 1709 se puso en escena la comedia De un yerro un gran acierto del conde de la Granja. ${ }^{88}$

Dentro de este ciclo festivo, las commemoraciones más significativas fueron los faustos por el nacimiento del heredero, ya que se aseguraba la línea de sucesión de los Borbones en el trono español. El 4 de noviembre de 1707 el cabildo eclesiástico celebró con un solemne novenario, con misa cantada y Sacramento patente, el embarazo de la reina.$^{89}$ El virrey presidió un Tedeum en el Callao, acompañado de repiques, fuegos de artificio y la representación de unas comedias en el patio del palacio. ${ }^{90}$

83 AHNC, FMC, 1211.1.4. Origen del llinatge Sentmenat. Genealogía de la familia de Sentmenat con memorias de sus gloriosos sucesos. S.f. El documento se redactó a mediados del s.XVIII, cuando Manuel, III marqués, poseía el mayorzargo.

84 Cortadillas i Vallès, Anna: Repertori de llegendes historiogràfiques de la Corona d'Aragó. Barcelona, Curial, 2001.

85 Rodríguez, José A.: "Entre Austrias y Borbones: la representación en Lima (1701) de la púrpura de la rosa de Calderón de la Barca". En: Reverte, C. y Reyes, M. de los (eds.): El teatro hispanoamericano en el Siglo de Oro. Cádiz, Universidad de Cádiz.

86 BNP, Breve relación de las Reales Fiestas con que la muy Noble y Leal Ciudad de Lima Corte del Perú celebró la Noticia de los felizes progressos que el año passado de 1706 consiguieron las armas de Nuestro Católico Monarca Filipo Quinto (que Dios guarde) contra el Exercito de los Aliados. Lima, Por Joseph de Contreras y Alvarado, Impressor Real. 1707.

87 Lohmann Villena, Guillermo: El arte dramático en Lima durante el virreinato. Madrid, CSIC, 1945, págs. 321-22. Lo que muestra como perduró hasta el cambio de siglo la influencia calderoniana en el Perú.

88 Sáenz-Rico, Alfredo: "Las acusaciones contra el virrey del Perú, marqués de Castelldosrius, y sus “noticias reservadas" (Febrero 1709)". Boletín Americanista, Año XX, n. o 28, 1978, págs. 128.

89 Bermúdez, José Manuel: Anales de la Catedral de Lima, 1534-1824. Biblioteca Digital Andina, www.comunidadandina.org/bda/docs/PE.CA0006.pdf, pág. 139.

90 AGI, Escribanía de Cámara, 548 (A). Juicio de Residencia del marqués de Castelldosrius. Declaración de don Garzia de Hijar y Mendoza, conde de Villanueba del Soto y marqués de San Miguel. 
En 1708, las "demostraciones mayores y más singulares" que se habían visto en la ciudad festejaron el nacimiento del príncipe heredero. Misas de gracias, vistosos altares, procesiones, al son de repiques de campanas, clarines, músicas y chirimías, luminarias y fuegos, con vivas a los reyes y al príncipe y a la "restauración de España" desde los balcones de palacio, mientras se arrojaba plata a la plaza y calles adyacentes. La celebración culminó con la puesta en escena de la comedia recordada como "la grande", ${ }^{91}$ seguida de fiestas de máscaras, "de diversas ymbenciones" y de corridas de toros, durante dos meses y ante las distintas instituciones y corporaciones coloniales - tribunales, cabildo eclesiástico, consulado, militares, ordenes religiosas, gremios-. Fiestas que fueron consideradas por algún contemporáneo como "las demostraziones mayores y más singulares" vistas jamás en Lima. ${ }^{92}$

En palabras del virrey, los actos se iniciaron el 15 de septiembre, con la representación en palacio del El mejor Escudo de Perseo, "una comedia de espeziales músicas prespectivas y mutaziones". ${ }^{93}$ Compuesta de loa y comedia, según J. A. Rodríguez, era una readaptación de la auspiciada en 1694 en Portugal, donde su embajada debía mejorar las relaciones con España y frenar la alianza de Portugal con Francia, por lo que recurrió al teatro como instrumento político y celebró entre 1692 y 1695 el natalicio del príncipe Juan. ${ }^{94} \mathrm{G}$. Lohmann se refiere a ella como una "comedia harmónica", que intercalaba pasajes cantados por zagales y zagalas, escenificada en el jardín de palacio, con una compleja escenografía. ${ }^{95}$ J.A. Rodríguez destaca el lujo de la representación, en la que los versos se compaginaban con música y el aparato de tramoyas. Su impacto social indicaría que marcó un hito en la historia del teatro colonial en el Perú, si bien y en opinión de este autor, se inscribiría dentro de la tradición del drama mitológico español del s.XVII. ${ }^{96}$ Sin embargo, J.C. Estenssoro la consi-

91 Ibídem. Declaración de don Pedro Camacho, contador mayor del Tribunal de Cuentas.

92 Ibídem. Declaración de don Jorxe de Talabera, abogado y relator de la Sala del Crimen de la Real Audiencia.

93 Ibídem. Declaración de don Pedro de Quesada Maraber, escribano de Cámara.

94 Rodríguez, José A.: "Una pieza recuperada del teatro colonial peruano: historia del texto de El mejor Escudo de Perseo del marqués de Castell Dos Rius". En: Arellano, I.; Rodríguez Garrido, J.A. (eds.): Edición y anotación de textos coloniales americanos. Madrid, U. de Navarra/Iberoamericana, 1999, pág. 360. Se conserva en parte en el Ms. B2192 Poesías cómicas de la Hispanic Society de Nueva York.

95 Lohmann Villena, Guillermo: El arte dramático ..., págs. 325-327.

96 José A. Rodríguez: “Una pieza recuperada ..., pág. 354. 
dera la primera opera representada en el Perú con música compuesta por Roque Cerutti (1688-1760)..$^{97}$

En los tiempos difíciles de la Guerra de Sucesión, el virrey costeó de su peculio personal la obra - en torno a 40.000 pesos - y se defendió de los maledicentes para quienes hubiera sido "mejor aplicarlo al donativo", insistiendo en que había orden expresa del S.M. para festejar al continuidad de la dinastía,

"conbiene en este Pais promover y radicar el amor y cariño devido a nro Rey y como la materialidad que les imprisiona es tanta necesitan de que las exterioridades de Vítores, aplausos, y celebridades, les informe, de suerte que creo yo, que están precissa, esta demostración que todas las demás deven zederle". ${ }^{98}$

La obra pudo suponer un cambio de tendencia en el teatro colonial, con nuevas influencias del teatro clásico francés ${ }^{99}$ y de la música italiana.

Castelldosius era un gran aficionado a la música, en su inventario postmortem se anotaron cuatro cuadernos de música y diversos instrumentos, de ellos, tres guitarras fueron a parar a manos de su hijo Juan Manuel y se vendieron dos más en 50 pesos a Agustín Llamas y un clave al maestro organista en 80 pesos. ${ }^{100}$ Amplió el conjunto de la capilla de palacio hasta nueve componentes, en cuyo repertorio mantuvo obras eclesiásticas y tonadas de los maestros españoles Sebastián Durón y Tomás de Torrejón y Velasco, añadiendo composiciones de los italianos Graciani y Corelli, lo que llevó a Peralta a escribir que era "Governador que ha llenado el Palacio con instrumentos". ${ }^{101}$

El milanés R. Cerutti llegó al Perú con la corte virreinal y luego fue músico durante medio siglo en diversas catedrales andinas. ${ }^{102}$ Introdujo un

97 Estenssoro, Juan Carlos: Música y sociedad coloniales. Lima, 1680-1830. Lima, Ed. Colmillo Blanco, 1989, págs. 43, 88, 114 y 121. Según J.C. Estenssoro pudo orquestar varias obras de Pedro de Peralta - Triunfos de Amor y poder, Afectos vencen finezas - y su traducción de Rodogune de Racine, si bien no deja de considerar que pudo ser Torrejón, de considerar las opiniones de Peralta más proclives a la tradición calderoniana.

98 AHNC, FMC, 1261.4.51.

99 Según I. Bottineau Racine habría sido traducido antes de 1710, al igual que Les Femmes savantes de Molière, lo que mostraría la novedad de la influencia del teatro clásico francés del siglo XVII. Sin embargo, según G. Lohmann y J. de la Riva Agüero, Rodogune habría sido una obra de la década de 1720. Bottineau, Ives: El arte cortesano en la España de Felipe V (1700-1746). Madrid, Fundación Universitaria Española, 1986, pág. 330. Lohmann Villena, Guillermo: El arte dramático...

100 AHNC, FMC, 1231.7.213. Quenta general que don Antonio Marí, cavallero del Orden de Santiago, dio a los sres. Herederos y demás albaceas, 1711.

101 Lohmann Villena, Guillermo: El arte dramático..., págs. 323-324.

102 Composiciones suyas como Al campo sale María, Hoy la tierra produce una rosa han sido editadas en el CD El Gran Barroco. La mejor música barroca de Latinoamérica. JADE/ UNESCO/Programa Repsol YPF para la Música de Latinoamérica. 
nuevo repertorio, bajo el influjo musical y operístico italiano, difundió el "recitativo acompagnato, el aria da capo y el violín" y la notación musical moderna. ${ }^{103}$

La difusión de la música italiana era un hecho entrada la década de 1720, que ha dejado evidencias en la correspondencia de los hijos de Castelldosrius. Uno de sus corresponsales se hacían eco de la celebración de Santa Rosa en 1728 con fiestas y bailes. En casa de una tal doña Rosa se había celebrado un gran fandango, lo que le hacía exclamar que "esta esto que ni París" porque

"no hay quién no tenga maestro de minuetes pasapi bretana y guastala y florida quien esta que no piensa en otra cosa es Zavalita quien no da lo que save de danza franzesa por una cantidad grande esta tan desnucado que creo lo an de llevar a Sn Andres por qte de los minuetes asta las viejas y biejos a baylar que se hazen vajas ay aun q[ue] a Diez o doze m[aest]ros no pueden dar abasto a todos". ${ }^{104}$

En 1732 Diego Melchor Morales de Aramburu pedía a Félix de Sentmenat i d'Oms, que le enviara desde la península partituras musicales e instrumentos

"y que los papeles sean unos conciertos de música, i algunas cantadas i obras de los authores mas clásicos, i de mejor gusto que hubiere en la Europa como Coreli, Jiacono Faco Valenti Vivaldi Gcachi Verasini Torreli o Albinoni, pero si hubiere otros de mejor gusto que los rreferidos puede rrenunciar los $\mathrm{UX}^{\mathrm{a}}$, i imbirlos de su voto un Biolin bueno de los celebrado carmonenses con dos o tres oboes, i algunas cuerdas". ${ }^{105}$

\section{Academia literaria}

A partir del 23 de setiembre de 1709 y hasta pocos días antes de su muerte en 1710 organizó y dirigió en el palacio virreinal una Academia literaria. ${ }^{106}$ Presidida por el propio Castelldosrius, quién proponía los temas y rimas. La música precedía la lid poética.

103 Estenssoro, Juan Carlos: Música y sociedad coloniales...

104 AHNC, FMC, 1242.20.154. Carta de Francisco del Valle i Valdés a Felix de Sentmenat, Lima, 9 de setiembre de 1728.

105 Le notificaba que había llegado en la armada un paisano suyo, don Jaime, "gran tocador de violín", AHNC, FMC, 1242.20.85. Carta de Diego Melchor Morales de Aramburu a Felix de Sentmenat, Lima, 15 de julio de 1732.

106 B.N.P., Manuscritos Virreinato, C 27. Oración en elogio del vejamen que dio el Marqués de Castel dos rius a los ingenios de la Academia. Escribió las obras siguientes la elegante pluma del Contador Dn. Pedro de Urquizo. Lima, diciembre de 1709; C3819. Academia que se celebró en el real palacio de Lima, en el gabinete del Excmo. Sr. Marqués de Castell dos Rius, Virrey del Perú... Biblioteca Nacional, Madrid, Manuscrito 8722. Flor de Academias. Palma, Ricardo: Flor de academias. Lima, Oficina Tipográfica el Tiempo, 1899. 
Formaron parte de la Academia, entre otros: Pedro de Peralta Barnuevo y Rocha; Jerónimo Monforte y Vera; Pedro José Bermúdez de la Torre; Luis Antonio de Oviedo Herrera y Rueda, primer conde de la Granja; Miguel Sáenz Cascante, presbítero; fray Agustín Sanz, calificador de la Inquisición; Juan Eustaquio Vicentelo, marqués de Brenes; Juan de Roxas y Solorzano; Matías Anglés de Meca. ${ }^{107}$

De entre ellos destaca, Pedro Peralta y Barnuevo (1664-1743), que puede considerarse como el gran literato y erudito de la Lima del temprano s.XVIII. Políglota, catedrático de prima de matemáticas, cosmógrafo mayor del reino, historiador e ingeniero, ${ }^{108}$ llegó a ocupar el rectorado de la Universidad de San Marcos (1715-17), en su cargo de Cuentas y Particiones fue el encargado del ajuste de cuentas entre los herederos del virrey, consultor del Tribunal del Santo Oficio, consejero del virrey marqués de Castelfuerte, presidió una posterior Academia de Matemáticas y Elocuencia, y fue socio correspondiente de la Academia de Ciencias de París. Autor, como dijimos, de obras de encargo de contenido político, de textos científicos y de carácter dramático y lírico, como Triunfos de amor y poder (1710) y Afectos vencen finezas (1712), mantuvo correspondencia con el marqués de Villada, fundador de la Real Academia Española.

Pedro José Bermúdez de la Torre (1661-1746) era abogado, alguacil mayor de la Real Audiencia, consultor del Tribunal del Santo Oficio, rector de la Universidad Mayor de San Marcos ${ }^{109}$ (1698-99 y 1722-25), miembro de la Academia de Matemáticas y Elocuencia. Autor del diversas obras en alabanza a diversas autoridades virreinales ${ }^{110} \mathrm{o}$ de los textos en ocasión de su recibimiento, ${ }^{111} \mathrm{o}$ en obras literarias de trazos clasicistas.

107 Revello de Torre, José: Las veladas literarias del virrey del Perú marqués de Castelldosrius (1709-1710). Sevilla, Tip. Zarzuela, 1920, pág. 12.

108 AGI, A. Lima, 409, Carta del Obispo de Quito Virrey al Consejo, 20 de octubre de 1712. Se proponía encargar a Peralta, entonces catedrático de matemáticas, la enseñanza de cosmografía y arquitectura militar, al mismo tiempo que se solicitaba se le nombrara ingeniero mayor del Reino, cargo vacante por la muerte de Jean de Rosmain.

109 Mendiburu, Manuel de: Diccionario Histórico Biográfico del Perú. Lima, Imp. Gil, 193134, t. II, págs. 42-48.

110 Elogio panegírico ... a la carta pastoral del excelentísimo señor doctor D. Diego Ladrón de Guevara (1710); El Sol del Zodiaco (1717) y Hércules aclamado de Minerva (1745) en alabanza, respectivamente, a los virreyes Príncipe de Santo Buono y J.A. Manso de Velasco.

111 En el feliz. Oriente que a la Universidad de San Marcos hizo el sol de los Guevaras (1710) en elogio del virrey obispo Diego Ladrón de Guevara; Minerva triunfante (1724) certámen literario para el recibimiento del virrey marqués de Castelfuerte. 
Jerónimo Monforte y Vera, natural de Aragón, era considerado como un "poeta festivo". ${ }^{112}$

Luis Antonio de Oviedo Herrera y Rueda (Madrid, 1636 - Lima, 1717), conde de la Granja (1690), caballero de la orden de Santiago, estudió en la Universidad de Salamanca, corregidor de Potosí (1667-1671, 1674-1680) y de Huanuco (1701-1705). Escribió, entre otras obras, la comedia De un yerro un gran acierto, representada en el aniversario de Felipe V, el 19 de diciembre de 1709, ${ }^{113}$ Vida de Santa Rosa de Santamaría, editada en Madrid en $1711^{114}$ y Poema Sacro de la Pasión (1717).

En cuanto a la actividad literaria del virrey, se conserva al menos un poema en catalán en alabanza a las setas y su valor gastronómico, muy apreciadas en la gastronomía catalana; ${ }^{115}$ J.A. Rodríguez ha documentado parte de su obra poética que se conserva en The Hispanic Society de Nueva York. ${ }^{116}$ Quisiera remarcar una vez más la dificultad de un balance completo sobre su obra literaria, ya que hasta el presente ha merecido la atención su actividad en Perú, sin que exista un estudio de su obra en conjunto que integre su producción en catalán y en castellano.

El ambiente cultural de la Cataluña de aquel entonces nos puede aportar algunas pistas para comprender el proyecto peruano de un miembro de su nobleza. J.A.Amelang ${ }^{117}$ ha señalado como en la Barcelona del cambio de siglo, la Academia dels Desconfiats actuó de aglutinador de un sector importante de la nobleza y la burguesía en ascenso. Fundada en 1700, se mantuvo activa hasta 1703; las sesiones tuvieron lugar en el Palau Dalmases, bajo la advocación de la Virgen de Montserrat, sus actividades fueron a la vez literarias y musicales. Elitista, estuvo integrada por aristócratas urbanos, eclesiásticos y nobles, como Pau Ignasi Dalmases i Ros; Francesc de Josa i d'Agulló; Joan Antoni de Boixadors i de Pinós, marqués de Savallà; Josep de Taverner i d'Ardena, quien sería obispo de Solsona y Girona; Felip Ferran i Saciera, conde de Ferran; Josep Clua i Granyena; Llorens de Baturell i d'Erill; Alexandre de Palau i d'Aguilar; Joan de Pinós

112 Mendiburu, Manuel de: Diccionario..., t.VII, pág. 413.

113 Revello de Torre, José: Las veladas literarias..., pág. 15.

114 Mendiburu, Manuel de: Diccionario..., t.VIII, págs. 299-312.

115 Real Academia de Bones Lletres de Barcelona, Manuscrit 9, En alabança dels bolets. Romans compost per lo excel.lentíssim marquez de Semmanat, que fou en temps de Carlos segon embaxador en França y Portugal y després elegit virrey de Perú. Debo esta información a Albert Rossic.La confusión con la otra rama del linaje, los marqueses de Sentmenat, se resuelve con las referencias a los cargos que ocupó.

116 The Hispanic Society, Nueva York, Manuscrito B2192, Poesías cómicas.

117 Amelang, James S.: La formación... 
i de Rocabertí; Josep de Rius i de Falguera, rector de la Universidad de Barcelona y Cervera; Agustí de Copons i Copons, marques de Moja; Antoni de Paguera i d'Aimeric, marqués de Foix; Martí Díaz de Mayorga; Francesc de Junyent i de Vergós, marqués de Castellmeià; Josep Amat de Planella i Despalau, ${ }^{118}$ marqués de Castellbell. ${ }^{119}$

Si bien Castelldosrius no participó directamente en ella, ya que se hallaba en París o camino del Perú, conocía o mantenía relaciones con buena parte de sus integrantes y, en parte, el modelo de academia y ciertos gustos musicales ${ }^{120}$ que impuso en Lima. Mantuvo correspondencia con Antonio Rubí y con Josep Galcerán de Pinós i Rocabertí, con quienes cruzó información relativa al Brazo Militar de Cataluña. ${ }^{121}$ Pablo Ignacio Dalmases y Ros, considerado uno de los grandes intelectuales catalanes de su tiempo, le pidió su intercesión ante las autoridades francesas para que se pudiera copiar la Crónica de Cataluña de Gerno Pujadas, que se hallaba en la biblioteca del arzobispo de Reims, tras ser expoliada de Barcelona durante la guerra de 1640, por Pedro de Marca, arzobispo de París. Dalmases presuponía que estarían "llenos de apuntamientos y notas pertenecientes a nra patria", con lo que "lograra Cataluña la manifestación de sus mejores glorias". ${ }^{22}$

Los avatares de la Guerra de Sucesión, situaron a los académicos catalanes en su mayor parte del lado austriacista, en posiciones políticas y militares destacadas, como fue el caso de Pau Ignasi Dalmases, embajador ante Inglaterra. Mantendrían una postura pro-borbónica sólo una minoría, entre la que destacó Francesc de Junyent. Personalmente Castelldosrius se alejaba de los académicos catalanes por su decidido afrancesamiento interesado de última hora. Señalemos que uno de los pocos académicos que siguieron la causa de Felipe V, Francesc Junyent, formó parte de un linaje que, como el de Castelldosrius, optó por encauzar a sus varones por la carrera militar, lo que les llevaría a puestos clave dentro de

118 Padre del que sería virrey del Perú: Manuel Amat i Junyent.

119 Muntada i Articles, Marta: "Els integrants de l'Academia dels Desconfiats (Barcelona, 1700-1703)”. Boletín de la Real Academia de Buenas Letras de Barcelona, XLVIII, 2001-2002, págs. 11-84.

120 En este sentido es ilustrador el estudio de la relación con la música del primer presidente de la Academia dels Desconfiats en Dolcet, Josep: "El compte de Savallà: un aristòcrata del Barroc i la seva música”. Boletín de la Real Academia de Buenas Letras de Barcelona, XLV, 1995-6, págs. 131-189.

121 AHNC, FMC, 1242.423. Cartas de Antonio Rubí, 1682; 1242.370 y 1241.15.140. Cartas de y a Josep Galcerán Pinós i Rocabertí, 1689-1690.

122 Biblioteca de Cataluña, Manuscrito 618. Cartas de Pablo Dalmases i Ros al marqués de Castelldosrius, Barcelona 31 de marzo y 22 de junio de 1704. 
la administración estatal borbónica a lo largo del s.XVIII, como se demostraría en su sobrino, Manuel Amat i Junyent, capitán general de Chile y virrey del Perú (1761-76).

G. Walker describe a Castelldosrius como un personaje que se veía a si mismo, en cierta forma, como un Luis XIV peruano, en su sala de espejos y jardines a la francesa en palacio, vestido a la moda gala, mecenas de las artes y libertino. Según este autor, su estancia parisina debió ponerle en contacto con el modelo de Academia organizado en torno a Luis XIV y sobre todo con el ambiente de libertinaje que se respiraba en la Académie Royale de Musique. ${ }^{123}$ Si bien no podemos despreciar el influjo de la Academia dels Desconfiats de Barcelona, el modelo parisino fue el que le dejó mayor impronta, al sugerirle una academia dirigida y auspiciada desde el poder. ${ }^{124}$

G. Walker apunta que sus fines eran mejorar su deteriorada posición, ya que, lejos de iniciar sus actividades artísticas desde su llegada al Perú, sólo organizó la Academia cuando fue consciente del peligro que le suponía la fuerte oposición de amplios sectores criollos. Para apoyar su argumento, señala que la representación del Mejor Escudo de Perseo tuvo lugar tres meses después que se iniciara la campaña en su contra en 1708 y que la Academia inició sus sesiones cuando necesitó revertir el descontento creciente. ${ }^{125}$ Sin embargo no podemos dejar de destacar que sus detractores siempre mencionaron su pasión por las artes.

\section{Bibliófilo y coleccionista}

Hombre de una amplia cultura, escribía en catalán, castellano, francés e italiano; a su muerte poseía en Lima 584 libros de diferentes temas e idiomas, ${ }^{126}$ que serían vendidos en 2.000 pesos, aunque se consideró que podría haberse alcanzado los 2.500 pesos si se hubieran rematado al menu-

123 Walker, Geoffrey J.: "El marqués de Castelldosrius, virrei del Perú (1707-1710)". En: Actas Primeres Jornades d'Estudis Catalano-Americanes, Barcelona, 1985, págs. 185-202.

124 Rodríguez, J.A.: “La voz de las repúblicas”..., págs. 257-261.

125 Walker, Geoffrey J.: “El marqués de Castelldosrius, ..., pág. 198.

126 Los datos aportados en este apartado se basan en: Archivo General de la Nación, Lima, Protocolos, Diego de Castro, 1689-1719, Inventario de Bienes del Marqués de Castelldosrius, 21-28 de mayo de 1710, ff.1047 y ss.; AHNC, FMC, Quenta General que Don Antonio Mari Cavallero del Orden de Santiago dio a los Señores herederos y demás Alvazeas del Excmo. Señor Marqs de Castelldosrius de los vienes que quedaron por fin y muerte de su Exa. Lima, 13 de setiembre de 1712. 
deo. ${ }^{127}$ Es difícil saber el origen y contenido de la biblioteca del marqués, aunque pudo ser en parte originada en el propio Perú, como apuntaría la deuda de 200 pesos a Gerónimo Monforte por un juego de libros del Pe. Quilquerio, comprados pocos días antes de su muerte.

Su saber matemático se constata porque poseía una tabla pitagórica de marfil ${ }^{128} \mathrm{o}$ en sus instrumentos de bronce matemáticos, vendidos a don Pedro Peralta en 650 pesos. Don Miguel Núñez adquirió los instrumentos náuticos y un anteojo de larga vista en 200 pesos; Fausto Vega compró dos anteojos de larga vista en 24 pesos y un tercero pasó a manos de don Agustín de Ulloa. ${ }^{129}$

Castelldosrius debió ser un hombre elegante en el vestir, introductor de la moda francesa que incluía peluca, ya que sus trajes fueron vendidos en 3.100 pesos y el conjunto de su ropa y ajuar en 7.948 pesos 4 reales.

Se conservan al menos tres de sus retratos. Un óleo de autor desconocido se halla inventariado con el número 28 de la serie de retratos de virreyes del Museo Nacional de Arqueología e Historia del Perú y reproduce la imagen del marqués de cuerpo entero. Los otros dos son de medio cuerpo, uno debió viajar a Cataluña con sus hijos y hoy se halla en la colección de los marqueses de Castelldosrius, ${ }^{130}$ y el otro se incluyó en el Libro de los Virreyes del Perú, ${ }^{131}$ que Mendiburu atribuye a Vivero y que habría sido dibujado y litografiado por Evaristo San Cristovál. ${ }^{132}$ Podemos señalarlos como de factura menor, se le muestra con los atributos de su cargo, su escudo de armas nobiliario y vestido a la moda francesa, con lo que seguía el modelo fijado en el retrato de Felipe V de 1707, obra de Rigaud. ${ }^{133}$ Ésto

127 Se anotaron otros seis libros, descritos con cubiertas de plata y otros con cantoneras, valorados en 400 pesos — entregados a su hijo Félix —, y varios breviarios usados, vendidos en 60 pesos a Joseph Razón. O los dos libros con cubiertas de terciopelo carmesí con cantoneras de plata de las fiestas de la Universidad.

128 Tabla de multiplicación.

129 Algún indicio indicaría su interes de vieja data por las ciencias exactas, como la carta de 1704, en la que Juan de Muxica le agradecía y daba acuse de recibo de unos "Ynstrumentos Mathemáticos". AHNC, FMC, 1242.19.320. Carta de Juan de Muxica, Madrid, 30 de julio de 1704.

130 Su reproducción en: Enciclopedia Catalana, t.VIII, pág. 66.

131 Galende Díaz, Juan Carlos: "El libro de los virreyes del Perú: una fuente documental para la historia de América”. Anuario de Estudios Americanos, T.LII, núm.1, 1995, pág. 228.

132 Mendiburu, Manuel de: Diccionario..., pág. 236, nota 1.

133 La nueva moda se reprodujo por igual en el virreinato de Nueva España, donde el virrey coetáneo, duque de Alburquerque, fue retratado siguiendo el modelo fijado por Rigaud, como puede comprobarse en el estudio sobre la iconografía de los retratos de virreyes en Nueva España en: Rodríguez Moya, Inmaculada: La mirada del Virrey. Castellón, Universidad Jaume I, 2002, pág. 201. 
último indica la inmediatez de la circulación en Indias de las nuevas tendencias artísticas que impuso la nueva dinastía. ${ }^{134}$

No sólo se preocupó de enaltecer sus blasones y grandeza nobiliaria a través de la literatura, sino que encargó e incluyó un grabado de su escudo nobiliario en Lima triumphante, ${ }^{135}$ obra de fray Michael Adame, sin duda el mejor grabador del momento en Perú. Encontramos su rastro en el inventario post-mortem, donde se anotaron dos láminas de cobre, además de un paño de corte con las armas del marqués y 7 reposteros Dorados con las armas de su exa.

La decoración del palacio virreinal era considerada propiedad del virrey, por lo que cada relevo suponía decorarlo de nuevo. Los cuadros se disponían en las diversas estancias palaciegas, si bien se hallaban ausentes en la sala de audiencias adornada con colgaduras de Damasco y la cansina del jardin, en cuyas paredes colgaban espejos siguiendo el modelo de Versalles.

El análisis de la temática de las pinturas y tallas que poseía a su muerte nos puede acercar al personaje, en lo relativo a la iconografía que lo acompañó en el ejercicio del poder. Entre las obras de iconografía ligada al poder, destacan dos retratos de Felipe $\mathrm{V}$ - uno ecuestre ${ }^{136}$ y otro de medio cuerpo- y uno de la reina, además de otros de Luis XIV y el Delfín. ${ }^{137}$ Una muestra de su afrancesamiento que debió impresionar a los limeños, y que pudo ser un indicador más de los nuevos tiempos en que la moda en el vestir a la francesa se iba imponiendo en la sociedad sudamericana. ${ }^{138}$

Tuvo en su poder reproducciones del certamen poético en la Universidad, de El Mejor Escudo de Perseo y su coreografía. ${ }^{139}$ Varias telas eran

134 El modelo fijado por Rigaud pronto fue incorporado a buen número de retratos de la época, una moda que se mantendría hasta bien entrado el siglo XVIII, como prueban los retratos de los virreyes príncipe de Santo Buono y marqués de Castelfuerte, atribuido éste a Cristóbal Daza y el de Pedro Peralta Barnuevo, conservado en el Museo de Arte Moderno de la Universidad Nacional de San Marcos, Lima, obra de Cristóbal Aguilar.

135 Estrabidis, Ricardo.. El grabado en Lima virreinal. Documento histórico y artístico (siglos XVI al XIX). Lima, UNMSM-BCP, 2002, pág. 317, lámina 109.

136 Fue vendido a don Francisco Antonio Calderón por 200 pesos.

137 Retratos de Luis XIV y el Delfín se hallaban así mismo en poder de los Bravo de Lagunas Castilla y Zavala, según señala Rizo-Patrón, Paul: Linaje, Dote y Poder. La nobleza de Lima de 1700 a 1850. Lima, PUCP, 2001, pág. 69.

138 Para el caso chileno y los cambios en la moda en el vestir véase Cruz de Amenabar, Isabel: El traje. Transformación de una segunda piel. Santiago de Chile, Universidad Católica de Chile, 1996.

139 Los bastidores y materiales descritos como un Atlas de Madera sustentando un marco dorado con una perspectiva de la fabula de Perseo y la comedia se vendieron a su muerte a don Gerónimo Tabuada en 650 pesos y en 10 pesos un marco dorado de tres cuartos con "la pintura de la Comedia en cartones". 
de escenas urbanas - Lima y su plaza, La pila de la plaza y El puerto del Callao-, de los centros mineros más importantes - Huancavelica, el cerro de Potosí-, historicistas como el de una batalla o indeterminados, anotados como perspectivas, países - al menos 40- y mapas —unos 16- Uno de éstos era de Saboya, de donde era la reina, con lo cual el tema se acerca a imágenes de poder.

Cuatro láminas se identificaron como pintura de porcelana de México, un indicador de la circulación de obras de arte entre México y Perú. Poseía dos cajoncitos con unas figuras de piedra de Guamanga, que bien pudieran ser un antecedente de los actuales retablos huamanguinos, reflejo de la estimación por la escultura en piedra de Huamanga.

Predominaban las obras de iconografía religiosa: un crucifijo de plata, la oración del huerto, el cordero místico, un país de la Creación del Mundo, la procesión del Nombre de María en la plaza de Lima, Nuestra Señora de Belén, ${ }^{140}$ la virgen del Calvario, Nuestra Señora del Rosario, ${ }^{141}$ San José, San Pedro, San Juan Evangelista, San Gregorio, San Ambrosio, San Bernardo, San Ignacio, San Francisco Xavier — dos cuadros y una talla-, San Antonio - una talla-, Santa Teresa, tres lienzos de San Francisco de Paula, Santa Rosa y fray Martín de Porras. Además su muerte impidió que se finalizara su encargo al corregidor de Cuenca, Ambrosio Pérez Romero, de una "gradería y pilas de piedra" cuyo destino debía ser la Iglesia de Panamá, cuando ya se habían gastado 633 pesos de los 2.000 presupuestados.

Destacan apóstoles, como San Pedro y San Juan Bautista; doctores de la iglesia, como San Ambrosio, el cisterciense San Bernardo de Claraval, San Gregorio el Magno, San Francisco de Paula, fundador de la orden de los Mínimos, defensor de la humildad, taumaturgo, con dones proféticos; santos de la contrarreforma, como los jesuitas San Francisco Javier (dos cuadros y un bulto), San Ignacio de Loyola, Santa Teresa y sobre todo llaman la atención la posesión de imágenes de advocación criolla como la Virgen de Belén, pero sobre todo Santa Rosa y fray Martín de Porras, quizás prueba de la importancia de su culto, pero también del interés del virrey por acercarse a las devociones en boga en el Perú de inicios del s.XVIII. En tal sentido uno de los testigos de su juicio de residencia mencionaba las

140 Se trataba de una lámina "de $3 / 4$ de alto pintura romana con marco negro y sus cantoneras de plata y su vidriera y cortina”.

141 Reclamada años más tarde por doña Rosa Ureta. AHNC, FMC, 1242.21.116. Carta de Gonzalo Cayetano de La Torre al III marqués, Lima 9 de febrero de 1721. 
novenas a San Francisco Javier "de quien era muy devoto" y a Santa Rosa en la Capilla Real de su Palacio, ${ }^{142}$ una estancia que había restaurado especialmente.

Desconocemos si el marqués trajo consigo de Europa el conjunto de las obras de arte que poseía. Me inclino a pensar que pudo embarcar los retratos de los monarcas españoles y franceses y que adquirió las restantes en Lima. En ello abundaría el hecho que aquellos de temática realista y urbana sólo podían proceder del mercado interno de arte. Eran también de factura local los cuadros de advocaciones criollas y probablemente buena parte de los de motivos religiosos, ya que su temática no era ajena a la iconografía del arte colonial peruano, como es el caso de San Ambrosio, San Bernardo de Claraval, San Gregorio Magno o San Francisco de Paula, de los que existen obras de pintores tan destacados como Diego Quispe Tito o Antonio Sinchi Roca. ${ }^{143}$ Buena parte de la colección del virrey fue vendida en el mercado limeño. ${ }^{144}$

Algunas de las imágenes remiten a sus vínculos personales. Así fue un mínimo quien trasladó en 1708 a España parte de sus remesas destinadas a sus hijos y para cubrir sus deudas pendientes, lo que muestra una cierta vinculación con la orden fundada por San Francisco de Paula. En el caso de las devociones de origen peruano, cabe recordar que su confesor, el sacerdote José Ruiz Cano, quien actuó como intermediario suyo en Madrid y lo defendió de ser destituido, había viajado como agente del cabildo eclesiástico limeño para promover la santificación del entonces beato obispo Toribio de Mogrovejo. ${ }^{145}$

142 AGI, Escribanía de Cámara, 548 (A). Juicio de Residencia del marqués de Castelldosrius. Declaración de don Gabriel de Mena, secretario de Cámara del Tribunal de Cuentas.

143 Schenone, H.H.: Iconografía del arte colonial: los santos. Buenos Aires, Fundación Tarea, 1992, I, págs. 128, 192 y 405; II, pág. 433.

144 Nuestra Señora de Belén, con marco de ébano y cantoneras fue adquirido por fray Pedro Pietro en 300 pesos; el retrato del rey a caballo por don Francisco Antonio Calderón en 200 pesos; dos "menores de prespectiva" en 50 pesos, Santa Rosa por Nicolás Paredes en 16 pesos; otros entre los 10, 16 y 25 pesos; 33 países por Lucas Manrique en 2 pesos cada uno; otros 13 países se remataron en 12 reales cada uno; el lienzo mediano del puerto del Callao en 2 pesos y el lienzo de papel del certamen de la Universidad por nada. El crucifijo de madera negra y marfil se vendió en 50 pesos y cuatro de las tallas de madera en 100 pesos. Quizas por la atonía del mercado de arte se dejaron en Palacio 24 lienzos de distintos tamaños y de poco valor, tasados en 200 pesos, más 8 laminas valoradas en 40 pesos. En poder de sus hijos, Félix y Juan Manuel, quedaron 8 lienzos grandes - Huancavelica, el cerro de Potosí, la procesión del Nombre de María en la plaza de Lima, la virgen del Calvario, "vendedoras" y dos de fray Juan Mesías y Nuestra Señora de Belén—, más las cuatro láminas de porcelana de México.

145 Éste emprendió viaje a Europa, con licencia y sueldo del cabildo eclesiástico, como agente en Roma para la canonización de Toribio de Mogrovejo, en Bermúdez, José Manuel: Anales ... pág. 141. 
En cualquier caso, el predominio de motivos religiosos se hallaba dentro de lo habitual en la época, tanto en París ${ }^{146}$ como en Barcelona. ${ }^{147}$ Ante la inexistencia de estudios sobre el mercado de arte peruano, baste aportar una cita irreverente del viajero francés Amadeo Frezier, sobre la decoración de las casas de Lima donde estuvo a poco de morir el virrey

"La única tapicería es una gran cantidad de malos cuadros que hacen los indios del Cusco". ${ }^{148}$

prueba de la difusión y éxito de la producción de arte colonial entre los sectores urbanos peruanos, de la que el virrey no escapo.

\section{Conclusiones}

La opinión del virrey sobre el Perú se fue moldeando con el tiempo, desde las grandes expectativas iniciales de ser la panacea de todos sus males, a la realidad posterior, cuando comprobó las dificultades crecientes para hacer realidad sus deseos desmedidos. Lo concibió como un lugar casi mítico, cuya imagen debía estar tejida de las noticias oídas de primera mano en París de negocios fabulosos de los comerciantes franceses, de las narraciones exóticas de viajeros o escritores en la distancia ${ }^{149} \mathrm{y}$ de aquellas que predominaban en el sentir de tantos aspirantes a altos puestos en la administración colonial de su tiempo.

En las cartas y documentos de Castelldosrius, hay muy pocas descripciones de la sociedad, costumbres, paisajes o cultura del Perú que conoció.

146 Crow, Thomas E.: Pintura y sociedad en el París del siglo XVIII. Madrid, Nerea, 1985, págs. 69 y ss.

147 Carbonell i Buades, Marià: "Pintura religiosa i pintura profana en inventarios barceloneses ca. 1575-1650". Estudis històrics $i$ documents del Arxiu de Protocols, XIII, 1995, págs. 137-190. Lencina Pérez, Xavier: "La història des del subjecte. Inventaris post mortem. Consum, microhistòria i cultura material a la Barcelona Moderna". Estudis històrics i documents del Arxiu de Protocols, XIX, 2001, págs. 199-242.

148 Frezier, Amadeo: Relación del viaje por el Mar del Sur(1712-14). Caracas, Biblioteca Ayacucho, 1982, pág. 225.

149 Monsieur Ducasse le encarecía que enviara "quelques animaux curieux" a Luis XIV AHNC, FMC, 1242.19.157. Cartas de Monsieur Ducasse, Bayonne, 9 de noviembre de 1706, Brest, 1707 y 29 de agosto de 1707. L.Feuillée se hacia eco del mito del Paititi al destacar la labor de los jesuitas en las conversiones, donde eran masacrados: “ils n'ont pas craint de porter depuis quelques années la lumiere de l'Evangelie dans le gran paititi, l'un des Empires le plus étendu \& le plus feroce de toute l'Amerique. Nous n'avons encore qu'une legere connoissance de ce vaste Empire". Feuillée, L.: Journal..., pág. 501. 
Un poco de acá y de allá, aparecen retazos, pequeños asomos de la Lima de principios del s.XVIII. La costa norte o Trujillo, donde pasó su primera Semana Santa, sólo aparecen mencionados. El resto del territorio, sólo surge cuando cita la entrada de comercio por los puertos de la costa - Arica, Ilo, Pisco-, o las provincias de arriba, cuando se hace mención de caudales, ingresos y evasiones fiscales de la minería, falta de circulante, comercio directo con los navíos franceses.

La percepción de Castelldosrius sobre el Perú debió estar teñida de cierta añoranza del París cortesano que había dejado, como vimos en sus comentarios sobre la parquedad de costumbres y diversiones limeñas, que encontró tan distintas a las parisinas. Eso parece traducir la opinión vertida al arzobispo d'Immola, nuncio de su Santidad en Francia, al que aseguraba que "es poquissima la satisfacción con que se vive". ${ }^{150}$ Su desencanto se extendió al propio ejercició del poder, padeció las dificultades y la complejidad del gobierno virreinal, que en cierta forma pendía de los complejos hilos de los pactos, dimes y diretes entre los distintos tribunales, instituciones y funcionarios. Así le contaba a su hijo Antonio que

"esto es un rebentadero sin momento de descanso porque no hay cosa que no haya de hacer el Virrey y de todas qdas dependencias concurren, no hay ninguna en que no se encuentre solapa y dificultad". ${ }^{151}$

Una cita que muestra sus complejas relaciones con amplios sectores criollos. P. Macera menciona sendas cartas de Castelldosrius, conservadas en archivos franceses, en las que se pone al servicio de Luis XIV. En 1704 manifestaba que serviría los intereses de Francia como los propios, lo que reiteraba desde Cádiz antes de embarcarse, comprometiéndose a mostrarle su devoción desde el virreinato del Perú. Sin embargo, en 1707, ya desde Lima, relativizaba lo antedicho y confesaba que le era imposible servir a los intereses de Francia como hubiera deseado. A pesar de su cambio de rumbo, "no obstante, el pueblo y la aristocracia de Lima, lo acusaban, como él dijo a Feuillée, de ser muy amigo de los extranjeros". ${ }^{152}$

En un sistema basado en las redes clientelares, donde el paisanaje o las alianzas matrimoniales con criollos eran determinantes para el arraigo

150 AHNC, FMC, 1241.15.86. Carta de Manuel de Sentmenat al Arzobispo d'Immola, Lima, 12 de enero de 1710.

151 AHNC, FMC, 1241.15.164. Carta de Manuel Sentmenat a Antoni de Sentmenar i d'Oms, Lima, 31 de agosto de 1707.

152 Macera, Pablo: La imagen francesa del Perú. Lima, INC, 1976, págs. 41-2, n.7. 
de los españoles en las Indias, Castelldosrius llegó al Perú con una corte extraña, contravino cualquier uso y costumbre, sin que pudiera encontrar un sector consolidado de origen catalán, que pudieran ser un apoyo y que difundiera una opinión más favorable a su persona.

Manuel d'Oms de Santapau introdujo de forma temprana un comportamiento cortesano ajeno a la tradición peruana de la época, con lo que abrió un modelo nuevo de cultura política, en la que el afrancesamiento, el establecimiento de nuevas redes y un enfasis singular en la cultura se convertían en divisa de su gobierno.

$\mathrm{Su}$ labor administrativa se distingue de sus predecesores en la medida que supuso la ruptura del pacto austriacista, por el cual la venalidad de cargos iba en beneficio de los criollos. El quebró tal tendencia y la revertió en su propio beneficio y en el de su clientela, o en el de los dictados de la Corona, escenificando "soy el poder y quiero usar el poder", con confusión de lo patrimonial con lo institucional.

El I marqués de Castelldosrius mantuvo una posición sin fisuras en pro de Felipe $\mathrm{V}$ —un botifler en la cultura política catalana-, aunque no llegó a ver los cambios que supondría el Decreto de Nueva Plata. Su testamento nos descubre a un hombre vinculado al Principado, que ponía sus bienes y hacienda bajo las leyes y fueros de Cataluña, condicionaba su herencia a la fidelidad de sus hijos a los Borbones y a la reconquista de Cataluña. Pidió ser enterrado en la Iglesia de Nuestra Señora de Montserrate, aunque su cuerpo descansaría en el convento Grande de San Francisco y sólo su corazón lo haría a los pies de la Virgen de Montserrat. Ésta se halla en una parroquia del cercado de Lima, que en el s.XVIII era regida por la frailes benedictinos catalanes, vinculados al Monasterio de Montserrat de Cataluña. Ernest Lluch ha demostrado como la advocación de la Virgen de Monserrat fue el aglutinador de los catalanes residentes en la corte de Madrid ${ }^{153}$ y Castelldosrius no se alejó de ese patrón de comportamiento. ${ }^{154}$

Los datos aportados sobre su actividad cultural y su testamento apuntan que, más alla de la cultura cortesana y la experiencia política adquirida en sus distintos destinos de funcionario, mantuvo patrones culturales, políticos o referidos al derecho hereditario que no pueden comprenderse sino

153 Lluch, Ernest: Las Españas vencidas del siglo XVIII, págs. 100-105.

154 Los vínculos de paisanaje se muestran en las noticias recibidas de Lima por el II marqués en carta de 24 de enero de 1727, donde se le notificaba la defunción del prior de Montserrate de "Nación Catalán”. AHNC, FMC, 23.12.1726. 
como pautas de comportamientos colectivos de amplios sectores catalanes tanto en el Principado como de aquellos que vivían en distintos territorios de la Monarquía Hispánica.

Buena parte de sus comportamientos políticos y culturales fueron producto de su afrancesamiento y de su origen catalán, dos influencias ajenas a la administración colonial de los Habsburgo y que se incorporaron con la nueva dinastía borbónica. Se trata de un quiebre inicial en el eje geográfico en el ejercicio del poder, el cual tenderá a bascular hacia la perifería peninsular a lo largo del s.XVIII. Castelldosrius adelantó, —aunque quedó trunco por su temprana muerte- un nuevo ejercicio del poder del que serían marginados los criollos, mientras que nuevas élites - militares, funcionarios, comerciantes - de distintas regiones a las castellanas se insertarían en la política, sociedad y economía colonial americana, en abierto conflicto con el statu quo criollo del s.XVII.

Político cortesano, convencido de la bondad de la literatura, la ciencia y las artes en el ejercicio del poder, la pluma de Julián Meza en su novela histórica La huella del conejo, lo ha incorporado en su personaje César d'Oms Piccolomini, ${ }^{155}$ a la vez el emperador romano o el papa Borgia, Manuel d'Oms y el Papa Pio II —Eneas Silvio Piccolomini-. ${ }^{156}$

155 Debo agradecer infinitamente a Cinco Continentes, libreros por amor y vocación, el regalo de la novela, inexistente en las librerías y bibliotecas españolas en el momento de redactar este artículo, depositada ahora en la Biblioteca de la Universidad de Girona.

156 Gutiérrez de Velasco, Luz Elena: "La historia reinventada". Estudios, 1991-92. 